\title{
Integrated Model for Green Purchasing Intention and Green Adoption: Future Research Direction
}

Liyana-arachchige Chandima Sajeewanie ${ }^{1, *}$, Mohd Shukri Ab Yajid ${ }^{2}$, Ali Khatibi ${ }^{2}$, S. M. Ferdous Azam² \& Jacquline Tham ${ }^{2}$

${ }^{1}$ Graduate School of Management, Management \& Science University, 122, Orchid Nivasi, thalahena, Malabe,Colombo, Sri Lanka

${ }^{2}$ Graduate School of Management, Management \& Science University, University Drive, Off Persiaran Olahraga, Olahraga, 40100 Shah Alam, Selangor, Malaysia

*Corresponding author: Graduate School of Management, Management \& Science University, 122, Orchid Nivasi, thalahena, Malabe, Colombo, Sri Lanka. E-mail: chandima213@yahoo.com

Received: June 29, 2019 Accepted: July 17, 2019 Published: July 23, 2019

doi:10.5296/jsr.v10i2.14996 URL: https://doi.org/10.5296/jsr.v10i2.14996

\begin{abstract}
People around the world realize that environmental concerns are one of the urgent problems facing every community. Green marketing practice is now expanding to the Asian region where environmental threats are disturbing governments and citizens. Environmental management and protection take a prominent place on the globe, where environmental pollution already harms the bio - diversity. The lack of adequate environmental legislation, weak policy decisions together worsened the situation. Therefore, immediate action is needed to protect the nation's environmental resources for the benefit of current and future generations. Since consumption is unavoidable for human existence, the green product is regarded as a means of reducing the environmental effects of human consumption. The introduction of green products in the consumer market has offered a better direction of consumption by decreasing the negative environmental effects of consumer products. Therefore green marketing was chosen as the theme to underpin the study. Green consumerism was chosen as the central theme in the green marketing paradigm. As a result, the integrated conceptual model was constructed to predict purchase intention and behavior towards green products. Altogether, eight antecedents as environmental attitude, environmental knowledge and awareness, perceived consumer behavior, habit, subjective norms, price, brand image, marketing information were incorporated in to the proposed model. Thus, the suggested model is regarded as the extensive model to predict intention towards green products. Furthermore, this model can indeed be introduced among customers at a global level to assess purchase intention and behavior towards green products.
\end{abstract}

Keywords: Green consumerism, Purchase intention, Consumer adoption and Integrated model 


\section{Introduction}

The Asian market is one of the major markets of international companies and they are enthusiastically engaged in introducing and promoting green products by using keen marketing strategies. The reasons for such engagement have described in some certain studies, one study conducted by Martinsons et al. (1997) stated that extraordinary utilization of resources, amazing economic development of numerous Asian countries created a lot of harmful influence on the environment whereby global as well as local attention on protection and upgrading of environment has improved . Then, according to Johri and Sahasakmontri (1998), a noticeable change in the environment was able to gain the attention of Asian people about prevailing environmental condition and problems. Next, according to the studies to protect the environment and for the sustainable development, the most of Asian countries' government bodies and companies are actively engaged in many activities whereby implementation of policies and business strategies are prominent (Johri and Sahasakmontri, 1998; Martinsons et al., 1997). Further according to the economists $\mathrm{Li}$ and $\mathrm{Su}$ (2007) explained that emerging Asian consumers are prepared to spend more than previous generation consumers as a result of the rising economic condition of Asian economies (Lee, 2012).

Hence according to Lee (2012) by foreseen the affluent green markets in Asia, companies of western countries are planning to invest in Asian market demand for green products in the near future. Even though international marketers are interested in investing in green demand of Asian consumers, it is a fact to be amazed that very little information is available about Asian consumers green products attitude and behavior. However green marketers are stressed that the availability of global market information on green behavior is very little. The inadequate level of information availability of international consumers' green behavior hinders the possibility of expansion of green products throughout the globe (Guru \& Ranchhod, 2005).

However, green product is one of the great solutions which reflect to prevent or reduce harmful environmental impacts on consumer life, yet the higher level of environmental concerns not essentially turn into actual purchasing of environmentally friendly green brands (Barker \& Ozaki, 2008). Rex \& Baumann (2007) noted that while considerable efforts have been made to make green brands more efficient and effective, their market share remains low. Some evidence suggested that Shoppers do not appear to have sustained desires for green brands in their buying behavior (Kilbourne \& Pickett, 2008) sales of environmentally friendly products did not reflect a gradual concern (Kilbourne \& Pickett, 2008) and also weaker relationships than expected.

\section{Theoretical Background: Underpinning Theories and Models of Green Consumer Adoption}

Theoretically, Green Consumer Adoption is viewed as the actualization of the low-carbon lifestyle (Sun, 2010), a fundamental representation of sustainable development (Liu \& Su, 
2011), and a modern, scientific, and healthy consumption pattern (Deng \& Liu, 2011). Specific Green Consumption objectives are outlined, including the adoption of green products that meet certain environmental standards (Rao et al., 2010; Yu, 2010), and reduction in total consumption and total waste ( $\mathrm{Li}, 2011)$.

The term green product, eco-friendly product, ecological product, environmentally friendly product interchangeably use in different studies (Kawitkar, 2013; Chen \& Chai, 2010). However, these terms include the meaning that green products are the products which make very minimal or zero impact on the environment whereby consist of strategies with recycling material, minimal usage of packaging and fewer unsafe stuff.

Greening contributes greatly to the triple end of the business: people, profits and the planet. However, greening requires a paradigm shift in green consumer behavior (Polonsky, 1994) and research uses different typologies to refer to this as environmentally friendly behavior, pro- environmental behavior, and environmental consciousness. The nature of the motivational factors associated with green behavior is rather distinct from that of the general consumer. Purchase decision of an ordinary consumer most likely considers personal costs and benefits, whereas the green consumer is unlikely to yield immediate personal benefits or pleasure, but rather future-oriented outcomes (e.g. a cleaner environment) that often benefit society as a whole (McCarthy \& Shrum, 2001).In this sense, the value orientations of customers (Social and cultural values, moral and ethical, political value) have found crucial factors of human behavior. Academic Research has already shown the direct links between personal values, attitudes, and health- food purchases (Homer \& Kahle, 1988).

According to Byron (2005), by studying the decision making process of consumers' marketers can understand their minds. This understanding helps marketers to create marketing mix, promotions and sales strategies. D'Souza et al. (2007) believe that the environment has an impact on purchase decisions of consumers. According to Young et al. (2010) in the context of green consumption, the process of decision making is very complex.

Ajzen (1991) stated that consumer behavior not merely directed by their wish and there are causes to do it so. The conclusion made by Ajzen (1991) was compatible with the theory of Planned Behavior. It explains how behavioral intention and purchase behavior of an individual influenced by attitude, Subjective Norms (SN) and Perceived Behavioral Control (PBC) .Hence, scholars conducted their studies to find the consumption behavior of green products(Tarkiaimen \& Sundqvist, 2005; Luo, 2010; Kim \& Chung, 2011; Kalafatis \& Pollard, 1999) by using the theory of planned behavior . Consumers' green purchase behavior is accepted as planned and targeted. According to Stern (2000) unavailability of sufficient amount of information created a requirement for further studies on green consumption.

Schiffman \& Kanuk (1997) state that the way consumers decide to spend their resources like time and money on things is the main focus for the study of consumer behavior. According to Karunnayake \& Wanninayake (2015) consumer behavior is a vast subject. Solomon (1996) considers it is a study of the processes involved in the purchase, usage or disposal of products, services, and experiences to meet the demands and desires of individuals or groups. Several researchers such as Dholakia (2001), Frey \& Jegen (2001) explain this process using the 
example of buying a vehicle as it is a carefully made decision.

\subsection{Theory of Consumer Behavior}

In literature, environmental consumers and their behavior have grown in recent decades with more empirical research to date. These research studies have followed two main streams related to micromarketing and macro marketing problems. The first stream of studies deals with micro- marketing problems related to consumer interest and environmental awareness. In this area, researchers attempted to define and describe the nature of green consumers and to segment those using different variables and classifications. These studies focused on evaluating the role of demographic, psychographic, behavioral and general environmental issues and other factors in segmentation and green consumer profile sketching. The second research section deals with macro- marketing (social marketing) problems concerning green consumer attitudes and micromarketing. The role of the macro environment (e.g. Socioeconomic, legal and political, technological) to influence the value and beliefs of individuals and society (Stern et al., 1995).These are considered important in shaping environmental attitudes (e.g. values, beliefs and standards), forming behavioral intentions and affecting the actions of individuals and consumers (Kilbourne \& Beckmann, 1998; Stern, 2000).

Theories and models of human behavior originate in all social sciences disciplines. In fact, disciplinary boundaries in many ways simply distinguish the types and contexts of human behavior in which scholars are interested, how behavior is defined and the methods by which it can be defined. In this sense, it would not be possible to attempt a comprehensive review of behavior theories. That said, attempts have been made to develop human behavior theories and models that transcend specific contexts. These efforts to isolate the key factors, procedures or causes of behavior are mostly psychological (especially social psychology) and sociological sources. Anthropology also provides considerable insight; particularly with regard to factors such as habit, ritual, and politics while the focus on power and organizational structure.

There are a number of ways of conceptualizing and defining a behavior. The greatest number of studies (mainly in psychology) emphases on the individual as the place of behavior. The external factors have a greater or lesser impact on these theories. Anyhow each behavior is the result of competing influences that are balanced and decided by the individual. In this context, individual behavior is conceived either as a continuum or at a certain discreet stage of behavior. For example, continuum theories can be used to predict how often a person can conduct a behavior such as looking for a green vehicle or number of inquiries made. Stage models are especially important in understanding the important factors that can influence personal choices and behavior at different points in their journey' to behavior.

Most other behavior theories probably move away from the individual to concentrate either on the behavior itself or on relationships between behaviors, people, social and physical environments in which they occur. Innovation theories such as diffusion of innovation and disruptive innovation theories focus in particular on the behavior itself as agents of change. Other sociological, anthropological and geographical investigations (such as the theory of 
social practice and socio-technical systems) have tended to focus on the behavior outcome of inter-relationships and shared social practice. From these points of view, people perform or reproduce behaviors that are themselves the product of relationships between people, their environment and the technology around them. In this sense, objects and environments play an active role in behavior production. These theories strongly draw on social theory.

Environmental/Green behavior theory would benefit greatly from more precise socio-psychological models and the roots of direct and indirect environmental behavior. They have been studied by many social psychologists over the past 50 years. The researchers tried to find the answer "why do people act environmentally? What are the barriers to pro-environmental behavior and how to overcome the green behavior gap and barriers? When and where environmentally friendly consumers able to find. In such an effort to respond to these practical challenges, researchers developed and scientifically tested numerous theoretical frameworks that illustrate the valid reasons for the gap between attitudes and behavior. The following section highlights various theories and theoretical models that have been developed to illustrate the connection between attitudes and behavior in general consumer behavior and green consumer behavior.

\subsubsection{Early US Linear Models}

The world's oldest and simplest models of pro-environmental behavior were based solely on a linear progression of environmental knowledge, leading to environmental awareness and concern (environmental attitudes).These rationalist models assumed that environmental education would automatically lead to more pro-environmental behavior and was referred to by Burgess et al. (1998) as' deceit' models of public understanding and action.

\subsubsection{Theory of Reasoned Action}

Theory of Reasoned Action (TRA) was defined in 1967 in an endeavor to provide a relationship between behavior and attitude (Fishbein \& Ajzen, 1975). TRA's main assumption is that individuals are rational in considering their actions and the implications of their actions (decision - making). Rational decision- making suppose that the decision is taken under uncertainty. Logical decision- making indicates that either best possible outcomes were expected or the decision-making unit was conscious of all the impacts and consequences.

TRA contains two concepts: "Principles of compatibility and the concept of behavioral intention" (Ajzen, 1988; Fishbein \& Ajzen, 1975). Principle of compatibility specifies that specific behavior that corresponds to the specific target, time and context should be assessed in order to predict a specific behavior aimed at a specific target in a given context and time (Ajzen, 1988; Fishbein \& Ajzen, 1988). The behavioral intention states that the motivation of an individual to engage in the behavior (Fishbein \& Ajzen, 1975). It suggests how much attempt a person would like to make to conduct such behavior. Greater commitment is more likely to ensure behavior will be conducted. TRA was criticized for ignoring the importance of social factors that could be a determinant of human behavior in real life .Therefore, in order to overcome the weakness of TRA, Ajzen (1991) proposed an additional factor in 
determining individual behavior in the Theory of Planned Behavior (TPB).

Fishbein and Ajzen preserve that people are fundamentally logical in ' systematically making use of available information to them ' and are not ' controlled by unconscious motives or overpowering wishes, ' nor is their conduct ' capricious or un-thoughtful' (Ajzen \& Fishbein, 1980; Fishbein \& Ajzen, 1975). Attitudes do not directly determine behavior; rather, they influence behavioral intention which shapes actions. Intentions are influenced not only by attitudes, as well as by social (normative) pressures.

Therefore ' the ultimate predictors of any behavior are the behavioral beliefs concerning their consequences and normative beliefs concerning the prescriptions of others ' (Ajzen \& Fishbein, 1980).

\subsubsection{Theory of Planned Behavior}

Theory of Planned Behavior (TPB) is the outcome of behavioral intentions, which then, in turn, are the consequence of an individual's attitudes to the problem, subjective norms and perceived behavioral control. Therefore the above theory has been competently used to determine environmental behavior (Harland et al., 1999; Kaiser et al., 1999).

TPB has been developed in response to the Theory of Reasoned Action (TRA). According to Ajzen \& Fishbein (1980) in terms of the Theory of Reasoned Action, intention is the main predictor in behavior. As such, if the consumer intends to engage in a particular behavior more and more, there is a high likelihood that the particular behavior will occur. Attitude and subjective norm contribute to making a decision.

The attitudinal determinant of intention is defined as the overall assessment of behavior. This consists of the salient belief that the likelihood of a result brought about by certain behavior is weighted by an assessment of that result. The attitude is defined as the "social pressure from others to perform or not perform certain behavior". "The Behavior Intention" is the personal which influences the final decision of the buyer. Attitude and subjective norm impact the behavioral intention. Attitude is an internal factor whereas subjective norm is external. Attitude consists of the salient belief and outcome evaluation. It is how a buyer would feel when he tries to do something. Subjective norm consists of motivation and normative belief to comply. It means that when people are trying to do something, they are under pressure which is created by family members, religious beliefs, etc. The suggestions made by these individuals have an impact on the behavioral intention.

Theory of Planned Behavior (TPB) seeks to explain the causal relationship between values, beliefs, attitudes, intentions, and behavior (Lane \& Stephen, 2006). Further, the extended model of the theory of planned behavior (TPB) use to predict the intention to adapt in to hybrid vehicles (Wang, et al., 2014).

Theory of Planned Behavior (TPB) is used by researchers like Han et al. (2010) and Luzar \& Diagne (1999) for better understanding of consumer preferences and behavior in development of service strategies. These researchers used it to understand the green behavior of consumers in order to develop marketing and service strategies for green products. TPB 
originates from the Theory of Reasoned Action (TRA) in which social factors are examined in this as part of the model. TPB is also used in various studies of consumer behavior in environmental issues (Aertsens et al., 2009; Arvola et al., 2008).

\subsubsection{The Model of Responsible Environmental Behavior (MREB)}

Hines et al. (1986) developed their Environmental Behavior Analysis Model of Responsible Environmental Behavior based on Ajzen \& Fishbein's (1980) Theory of Planned Behavior. They conducted a meta-analysis of 128 pro-environmental behavior research studies and found the factors associated with responsible pro-environmental behavior. Though this model has been emphasized as a much more advanced model than the TPB, the factors recognized are not empirically validated enough to explain pro-environmental behavior. The more factors connected with pro-environmental behavior, the variables described do not adequately illustrate pro-environmental behavior, especially the weak relationship among intention and actual responsible behavior. There may be many more factors affecting pro-environmental behavior, and Hines et al. (1986) stated those under situational factors such as economic constraints, social pressures, and prospects choose real behavior.

\subsubsection{Stern's Attitude-Behavior-Context Model (ABC Model)}

Amongst the most significant efforts in social psychological literature to overcome internal-external contradiction is the effort by Stern (2000) and his colleagues to develop incorporated Attitude-Behavior Context (ABC) models of environmentally significant behavior. The basic starting point for Stern's approach is to assume that behavior is a function of the organism and its environment.

The ABC language, $\mathbf{B}$ stands for Behavior, $\mathbf{A}$ stands for attitudinal variables and $\mathbf{C}$ for contextual factors. Attitudinal variables include a range of particular personal beliefs, norms, and values and also general pre-dispositions to act in some ways.

Contextual factors might include a wide set of factors such as: financial incentives and expenses, physical capabilities and constraints, institutional and legal factors, public policy support, interpersonal influences (e.g. social norms) and, in certain situations wider social context parameters such as allegiance to or influenced by environmental groups.

A key dimension of the $\mathrm{ABC}$ model is the structural dynamics between the influence of attitudes (i.e. internal factors) and contextual (i.e. external) factors. In general, when contextual variables are weak or non-existent, its supporters argue that the attitude-behavior link is strongest; conversely, there is practically no correlation among attitude and behaviors when contextual factors are either strongly negative or strongly positive.

\subsubsection{Triandis' Theory of Interpersonal Behavior}

There is one crucial element in behavioral psychology is still missing from Stern's ABC model, it is the role of habit. Stern (2000) admits this and suggests that such an integrated model of environmentally significant behavior could comprise of four factors: 1) attitudes; 2) contextual factors; 3) personal capacity, and 4) habits. Stern's proposal is quite similar to an effort being made almost thirty years ago by social psychologist Harry Triandis's integrated 
'interpersonal' behavior model. Traindis identified the crucial role that social factors and emotions play in shaping intentions and importance of past behavior in the present. Based on these observations, Traindis suggested a Theory of Interpersonal Behavior where intentions-as in many models-are immediate precedents of behavior. However, importantly, behavior is also mediated by habits and both these are moderated by facilitating conditions.

According to Triandis, behavior in any situation is partly a function of intention, partly of habitual responses, and partly of situational constraints and conditions. Both social and affective factors as well as rational deliberations, influenced on intention.

Triandis offers a specific role on behavioral intentions for affective factors. The effort to integrate emotional antecedents into a model of action has received a great deal of support in more recent writings (Bagozzi et al., 2002; Steg et al., 2001).

Triandis theory of interpersonal behavior depicts many of the criticisms leveled at the theory of rational choice in a manner which is not done by most of the other models. It might be used as a framework for empirical observation of the strengths and weaknesses of the component factors in different contexts. Much less use has been rendered of the work of Triandis than it was made of the work of Ajzen- Fishbein. However, it proves to have added descriptive value over Ajzen's model, in particular, while including beliefs, habits, and role.

\subsubsection{The Motivation-Opportunity-Abilities Model}

The Motivation-Opportunity-Abilities (MOA) model proposed by Olander and Thogersen in 1995 was another effort to build an integrative model for consumer actions. They figured to the advancements in explanatory power that can be achieved by integrating a concept of ' ability ' and a concept of facilitating conditions or 'opportunity ' to perform behavior into the model. As a simpler version of the Theory of Planned Behavior the motivation component of the MOA model can be recognized. Furthermore, Olander and Thogersen (1995) suggest several options, including use of the motivational aspect of the model of Triandis. Both habit and task knowledge element incorporated in the concept of 'ability'.

The previous Research on waste separation and recycling behavior (Kok \& Siero, 1985; Pieters, 1989) supported the importance of the model. Habit is not only an independent determinant of behavior but as well as a moderator of intention. The impact of situational factors on consumer behavior has been brought up several times in this review. The opportunity component of the MOA model is clearly connected to Triandis ' paradigm of facilitating conditions and Stern's notion of external conditions. Although Olander and Thogersen prefer to see opportunity as ' objective prerequisites for behavior, ' this element of the model also has commonalities with Ajzen's concept of perceived behavior control. There is simple evidence of the importance of situational factors as a precondition for proenvironmental behavior (Johansson, 1993; Thogersen, 1990; Guagnano et al., 1995).

The MOA model's crucial structural feature is its effort to integrate motivation, habitual and contextual factors into a single pro-environmental behavior model. It's even more valuable as energy behavior and mainly habitual behavior instead of conscious decision-making. 


\subsubsection{Diffusion of Innovation Theory}

The Diffusion of Innovation (DoI) theory emphasis on innovation as an agent of behavior change (Rogers, 2003).Subsequently, perceived attributes of an innovation that determine its adoption rate to a larger extent than the adopters ' traits. The DOI has also been widely applied to concerns such as marketing, development, and health .The theory argues four ' key elements ' of changes in behavior: innovation, communication channels, time and social systems (Rogers, 2003).

As per the DOI theory, behavior will alter more steadily if innovations are viewed as being better than the previous alternatives (relative advantage) and reliable with the existing values, experiences, and wants of prospective consumers (compatibility), if they become easy to grasp (complexity), testable via limited research (trialability) and their findings are identifiable (observability).

It illustrates the different functions of ' mass media ' and ' interpersonal 'channels, with the former being especially useful in raising awareness among prospective consumers and the latter being more successful in convincing actual adoption. Innovations are examined "via the subjective appraisals of close peers" instead of through specialists (Rogers, 2003), thereby close interpersonal interaction plays a key role. Social structures, called ' diffusion networks, ' are crucial to this theory as diffusion happens within them - they set the boundaries around diffusion. Innovation theory is a vast research area as well as, several valuable summaries; reviews are available (Wright, 2004).

\subsubsection{Stimulus- Response Model}

Customers make several purchasing decisions daily, as well as the purchasing decision is the focus of the marketer's attempt. To find out actual consumer purchase marketers can study what they buy, where, and how much .However it is not easy to find the reason behind why they buy products. Consumers themselves often do not precisely shape their purchases.

Marketers highlighted that the soul of the consumer is comparable to a computer with storage compartments in which brands or logs or distinguishable packages are stored in clearly labeled that can be controlled by superbly written ads or commercials simply do not exist. The key issue for marketers is: how would consumers react to the company's various marketing activities?

As a starting point to this Kotler (2013) developed a Stimulus-Response Model of buyer behavior. As explained in this model marketing and other stimuli enter the "black box" of the consumer and produce some response. Marketers have to figure out what's in the black box of the buyer. The four Ps: product, price, place and promotion comprise of the Marketing Stimuli. Other stimuli typically involve main forces in the environment: economic, technological, political and cultural.

These inputs enter the black box of the buyer, where they will be transformed into a set of observable buyer responses: the behavior of the buyer's brand and company relationship and what he or she buys, when, where, and how often (Kotler et al., 2013). 
The marketer tries to understand how well the stimuli are transformed into responses within the black box of the consumer, which has two parts. First, the attributes of the buyer impact how he or perceives and respond to the stimuli. Second, the decision process of the buyer itself influences the behavior of the buyer.

\subsubsection{Norm Activation Theory}

The Norm Activation Model (NAM) (Schwartz, 1977; Schwartz \& Howard, 1981) is one of the other models widely used in research on green consumption behavior. The difference between this model and the planned behavior theory is that the NAM is developed to explain behavior and is much more focused on the influence of others, while the TPB suppose that people are motivated by self-interest (subjective norms are also evaluated in terms of self-punishment and rewards).NAM illustrates the relationship among activators, personal norms and behaviors (Schwartz, 1970; 1975; 1977; Howard \& Schwartz, 1984). As per this theory norm activation refers to a process where people build self-expectations regarding social behavior. All such behavioral self-expectations are called 'personal norms' and are experienced as feelings of normal obligation. Four situational factors and two personality trait activators are central to the norm activation process .According to the NAM, awareness of need includes the degree to which a person's interest is concentrated on the existence of a person or a more abstract entity in need. Situational responsibility, the second activator refers to the degree to which an individual feels responsible for the consequences of the need. For example, when it is apparent that other people have caused the need, the possibility of potential actors feeling some accountability in this situation reduces (Schwartz, 1977). Pro-social behavior has been further strengthened by efficacy, referring to the degree to which behavior is described that may mitigate need.

The fourth activator, ability, refers to the perception of the performers about the availability of the resources or capabilities needed to perform the main behavior. Two personality trait activators reflect the idea that people are differently inclined towards social behavior in NAT. The receptivity of a person to situational signs of need refers as the awareness of the consequences.

Initially, NAM was developed and tested in the ground of interpersonal pro-social behavior (Schwartz \& BenDavid, 1976), but has now been widely applied in the environmental domain (Thogersen, 1996). Previous NAM, based environmental studies focused exclusively on two situational activators: awareness of the need and situational responsibility (Stern et al., 1986; Hopper \& Nielsen, 1991). However, these two activators might not provide a complete explanation of norm activation in association with moral (pro-environmental) behavior.

\subsubsection{Value-Beliefs- Norm Theory}

Stern (2000) suggested a similar model which was an extension of Schwartz's (1977) norm-activation theory. The Value-Belief-Norm theory was initially a justification of altruistic behavior but it was specially extended to pro- environmental behavior. Stern (2000) argues based on value theory, Norm-Activation theory and the new ecological paradigm, that personal norms are a crucial predictor that fills the gap in value action as personal norm as a 


\section{Macrothink}

Journal of Sociological Research

ISSN 1948-5468

2019, Vol. 10, No. 2

moral obligation over and above behavioral intent and stimulates actual behavior. With this argument, the study adopts human value orientations as a prerequisite for attitude formation and norms that determine actual behavior.

\section{Evaluation of Attitude- Behavior Theories}

Table 1. Key Features, Arguments and Weaknesses of Theories

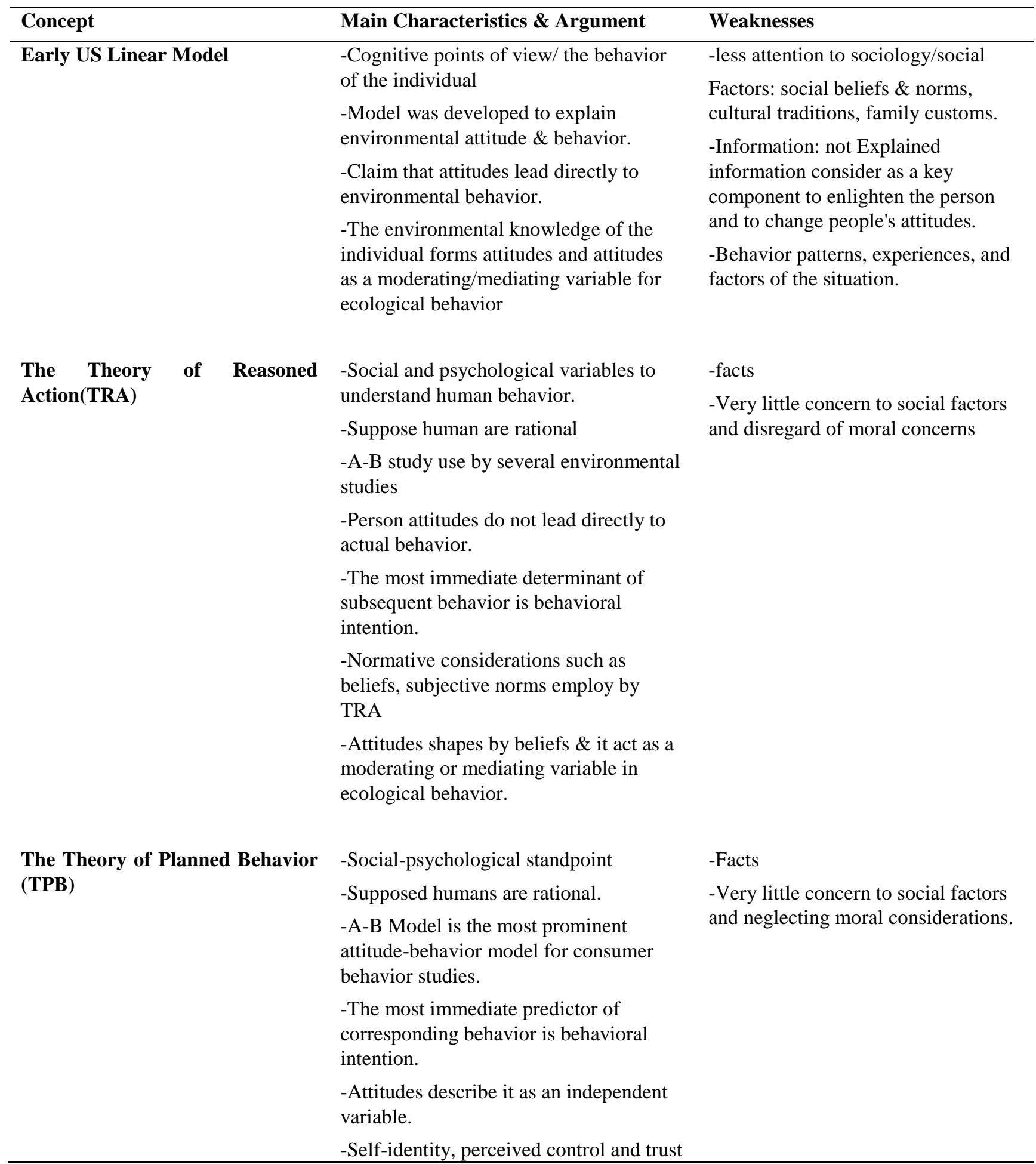


use as extended variables in TPB.

Model of

(MREB)
Responsible Behavior

-Focus more on Social- Psychological perspective.

-Analysis on pro- environmental behavior.

-Make an argument on the connection between knowledge and attitudes-attitudes towards intention and intention toward more real responsible behavior.

-Use situational factors as new dimension of A-B model.

$\begin{array}{ll}\text { Attitude- Behavioral Context } & \text { - Able to prevail over the } \\ \text { Model (ABC Model) } & \text { internal-external dichotomy. } \\ & \text {-Focus on environmentally significant } \\ & \text { behavior. } \\ & \text {-The systematic composition among the } \\ & \text { influence of internal factors and external } \\ & \text { factors is a key dimension of the ABC } \\ & \text { model. } \\ & \text {-When situational factors are weak or } \\ & \text { non-existent attitude-behavior ink is } \\ & \text { considered as strongest. Conversely, } \\ & \text { there is no relationship between attitude } \\ & \text { and behavior when situational factors are } \\ & \text { either strongly negative or strongly } \\ & \text { positive. }\end{array}$

Triandis' Theory Interpersonal Behaviour

Motivation-Opportunity-Abilities (MOA) model factors and emotions play in shaping of - Provides a specific role in behavioral intentions for effective variables.

-Acknowledged the major role that social intentions.

-The intention is affected by both social and affective factors along with rational deliberations.

-Figured to the enhancements in explanatory power this can be accomplished by integrating the concept of ' ability' and the concept of facilitating conditions or 'opportunity ' for behavior in the model.

-Include both an element of habit and an element of task knowledge.
-Task of habit

- Less empirical investigation and application.

- Less empirical investigation and application. 
Theory of Diffusion Innovation

Stimulus- Response Model

The Norm- Activation Theory (NAT)

The Value- Beliefs-Norm Theory (VBN)
-Focus on innovation as a major variable of behavioral change.

-Decide its adoption rate to a larger extent than the buyers ' characteristics.

- Widely studied issues like marketing, development, and health.

-Comprehensive.

-Emphasis on both internal and external stimulus of consumer.

-Argue that buyer's black box stimulated by marketing stimulus and other environmental factors.

-Very much about the psychological standpoint.

-Attitudes \& personality variables contribute to environmental behavior.

-The activation of "personal norms" is an crucial precedent for Pro-environmental behavior.

-Very much about the psychological standpoint.

-The antecedents of pro-environmental behavior are value orientations and personal norms.

-A significant antecedent for pro-environmental behavior is the activation of "personal norms." "VBN is more concentrated on the antecedents of attitudinal variables and personal strengths.

-The most immediate determinant of corresponding actual behavior is personal moral norm.

-Beliefs moderate or mediate the connection among values and personal pro-environmental norms.
- Do not focus on specific decision makers or social structures.

-Most of this analysis was carried out in an economically dominated context.

-The diffusion of innovation in other forms or with non-economic outcomes has been scarcely analyzed.

-Less empirical investigation and application.

- Very complex

-Facts

-Very little concern to social beliefs and norms.

\section{-Social Conviction}

-Facts.

-The model is averted by showing different characteristics of wider social, cultural, legal and economic situational elements, habits and experiences.

(Source: Adopted from Samarasinghe, 2012 and further developed by the Researcher.) 


\section{Commonalities, Contradictions and Omissions of Theories and Models}

Behavior is a complex issue and comprised of many various factors, both internally and externally .According to the literature review of theories and models there are two distinctly different approaches to understanding consumer behavior. One set of studies and models behavior are internal to the individual: values, beliefs, norms, attitudes and the other set of studies are external to the individuals such as institutional constraints, social practices, etc. The very first (' internal ') context holds an assumption of consumers as autonomous agents of social structure, while the second (' external ') context considers consumers as restricted operators programmed (or at least heavily inspired) by external influences other than their understanding or control. Not surprisingly, in their policy prescriptions, the two perspectives tend to vary extensively.

The internal approach asks primarily for awareness-raising, information provision, and marketing campaigns to encourage pro- environmental attitudes on the understanding that consumers attitudes as the most vital indicators of effective environmental behavior. To create the necessary conditions for pro-environmental behavior a combination of rewards and shifts in the regulatory system is required. For instance, recent literature on recycling tends to embrace both methods (Perrin \& Barton, 2001; Oates \& McDonald, 2004).

However, it doesn't always do so in a structured way and it is not applied in green vehicle literature. In particular, this literature does not always discuss in any depth the relationships between internal factors and external limitations.

In addition, the theory of Planned Behaviors is part of all integrated models in one way or another. Theory of Planned Behavior is not sufficient but it is used as a point of reference to analyze internal motivation factors. Therefore, habitual behavior takes into account by some models. Particular attention needs to be given to habitual behavior, as most energy behavior is habitual behavior. However, the intervention to influence this type of behavior is totally different from theory of planned behavior. All models have a basic starting point: determinants or factors that impact behavior must be developed since they describe behavior.

Thus, the internal and external determinants of the particular behavior must be examined at each time that wants to influence behavior. Moreover, determining the moral, habitual and social motives and situational factors that affect particular behavior isn't an easy matter and it can only be achieved unless they are examined for particular behavior in the given scenario (Moriss et al., 2012; Kollmuss \& Agyeman, 2002).

From the range of factors found in the models, it can be concluded that a consumer behavior model should have a wide array of various points of intervention, for instance by influencing the social and institutional conditions affecting the moral choice and social identity, and by addressing the situational conditions related to specific behavior. Moreover, the focus must be required to pay on the cognitive process of behavioral change.

The researcher has only examined some of those various models which have been formed to 
illustrate the gap in attitude - action and examine the obstacles to actual green behavior. In certain scenarios, all the models mentioned have some validity. This implies that the question of what shapes real environmentally friendly behavior is complicated one that it could not be conceptualized in a single framework. Therefore, such a single framework with all the variables that shape consumer behavior would be really complex and lose its practicality and its meaning (Kollmuss, \& Agyeman, 2002).

As discussed in table 01 there are commonalities, contradictions and omissions in the different models. The significant factors that influence on consumer behavior have been identified by reviewing 126 articles which are published in reputed journals in between year 2000-2017. To some extent, the differences and hierarchy between the various important variables are subjective. For instance the current study differentiates the following factors: external factors (e.g. price, subjective norms, brand image and marketing information) and internal factors (e.g. perceived behavioral control, Environmental knowledge and awareness, environmental attitudes, and habit).

The complexity and changing of behavior as mentioned in the literature discussed has led to several efforts to synthesize ' core ' components into integrated frameworks to advice policymakers and decision makers to understand the behaviors and how they might actively participate with them. This synthesis simply minimizes the sophistication of behavior and improves comprehensibility and usability (Jackson, 2005).

The researchers conclude from this that the most holistic approach to study behavior is an integrated approach. They claimed that even though adopting both approaches in recent literature, this is not done in a cohesive manner. They proposed that the interactions among internal and external and external factors must be explored if an integral model is chosen.

\section{Development of the Conceptual Model of the Study: An application of Integration Approach}

The Theory of Planned Behavior (TPB) is widely used to assess behavioral intention and behavior. (Bamberg et al., 2007; Kim \& Han, 2010; Abou-Zeid \& Ben-Akiva, 2011). As per the Ajzen (1991), a consumer's behavior is determined by the behavioral intention, which in turn is affected by three factors, notably attitude, subjective norm, and perceived behavioral control. The Theory of Planned Behavior (TPB) is now being successfully used in researches on environmental friendly behavior of consumers. For instance, the TPB model was used by, Chen and Tung (2010) to find out the behavioral intention regarding recycle waste where it was revealed that this is a useful to know about the recycling intentions of consumers. In research conducted by Sigurdardottir et al. (2013), the TPB model was used to determine the intentions of adolescents to travel by car or bicycle. Klockner et al. (2013) stated that determinative psychological factors such as attitudes and norms have an influence on the intention to adopt clean cars. According to Kaiser \& Scheuthle (2003) additional variables like moral beliefs are being added to the TPB theory making more improvements to the same. For example, Beck and Ajzen (1991) and Kaiser \& Scheuthle (2003) state that certain moral 
feelings are required to increase the explanatory power of the TPB model vis-à-vis assessing the intention of the consumer to perform certain environmental friendly behaviors.

Moreover, several studies look at the attributes instead of the effects of consumers ' internal motivations and needs (Afuah, 2002; Maurer, Pitzer, \& Sebastian, 2004; Haeger \& Storchmann, 2006; Ralf et al., 2007; Prado, 2009; Byrd \& Caldwell, 2011). Some of the factors leading to the attitude-behavior gap have been examined by scholars. Dobscha \& Ozanne (2001) and Laroche et al. (2001) have examined the environmentally friendly behavior of consumers, whereas the role played by consumer attitudes in green consumption has been examined by Kim \& Chung (2011) and Tanner \& Kast (2003). Loureiro et al. (2002), Olson (2013) and Van Doorn \& Verhoef (2011) are the researchers who have studied the tradeoffs that consumers are keen to make. However, internal factors and external factors that lead to the attitude-behavior gap have not yet been adequately researched. According to Corraliza \& Berenguer (2000) some of the previous research has briefly looked at the role played by external factors i.e. how the physical-environmental variables affect the consumer behavior. However, these writers highlight the inadequacy of research on external factors. As such, in researching these factors the focus should be on understanding better what consumers' motivations are and the issues relating to this opportunity.

It could be stated that while social psychologists claim that the values of people impact their thoughts (cognitive) and feelings (effective) towards human/consumer behavior, they may not always lead to real behavior and the gap in attitude/behavior associated with various factors (Samarasinghe, 2012). Besides that marketing theorist argues that environment, consumer characteristics, and customer decision process can lessen or overcome this gap, and the framework of these studies appears to be a model of consumer behavior (e.g., Model of Consumer Behavior, Kotler, 2013; ABC Model of Stern et al., 2000).

In Sri Lanka very few studies were done with relation to green consumer behavior. Among them only one study conducted to reveal determinants of purchase intention of green vehicles. But it not examines the determinants of actual adoption to green vehicles or reasons behind the value action gap. Systematic research effort to study consumers' internal factors and other external factors on purchase intention and green adoption has been lacking. As such, the present study represents a first step toward mending such research gap in Sri Lanka.

Consequently, the authors of the current study constructed a research model, following direction of the attitude- intention relationship as outlined above, and incorporating findings from past research, to examine this relationship. Specifically, the research model examines how consumers' internal and external factors impact on their green purchase behavior.

Studies in line with green consumerism have been initiated in Sri Lanka by the researcher Samarasinghe in 2012. She also suggested that, conducting the studies on antecedents of environmental awareness of cognitive, emotional / affective and behavioral aspects in the developing country like Sri Lanka surely give path way to develop the specific constructs and measures for Sri Lanka to explore the unique and prominent factors affecting on purchase intention and adoption. In this stand point, proposed model in this study is an original and unique, it is based on theories and models established in line with green consumerism. It 


\section{Mll Macrothink}

offers a very well-supported elaboration of green purchase intention and behavior as the new paradigm in green consumerism.

In this view point, this is directed to find the major drivers influenced on green purchase intention and adoption among green car owners in Sri Lanka. All in all, such knowledge or finding enables officials, educators, business organizations and policymakers in Sri Lanka and countries in the South Asian region to strengthen the green marketing culture amongst the public and thus minimize the harmful impact on the environment, which in turn develops the sustainable aspects in the long-term perspective.

The study builds up an integrated model of consumer purchase intention and behavior that highlights consumers' internal demands and sources of external influences to examine customer decisions when acquiring an environmentally friendly green car (hybrid car). Consequently, the current study constructed a research model, following direction of the TPB and incorporating findings from past research. The present study recommends a hybrid decision-making model with a two-stage approach for examining consumer behavioral patterns with distinct buyer characteristics that are regarded as their internal demand motives and external motives. The model proposes in this study is very comprehensive and corporate two major independent variables which have recognized through a comprehensive analysis of previous literature. In particular these internal factors and external factors are studied to determine whether they influence on green purchase intention and consumer green purchase behavior/adoption to green cars. The moderating effect of gender on purchase behavior also will be examined. As revealed in the literature review, by considering the limitations of TPB and with rigorous literature survey the present study engages with the comprehensive analysis to clearly investigate the major drivers which influence on consumer intention to adopt in to green cars (hybrid cars). Major drivers like internal factors and external factors were integrated into the TPB model to build and extend the TPB model. The findings of this study will confirm the fitness of the extended TPB model and confirm that the extended TPB model has strong explanatory power in predicting consumer adoption in green cars. The model created for this research is therefore unique. It is based on the theories and models developed in line with green consumerism. It also offers a well-supported elaboration for green purchase intention and adoption as the embedded model in green consumerism. 


\section{I Macrothink

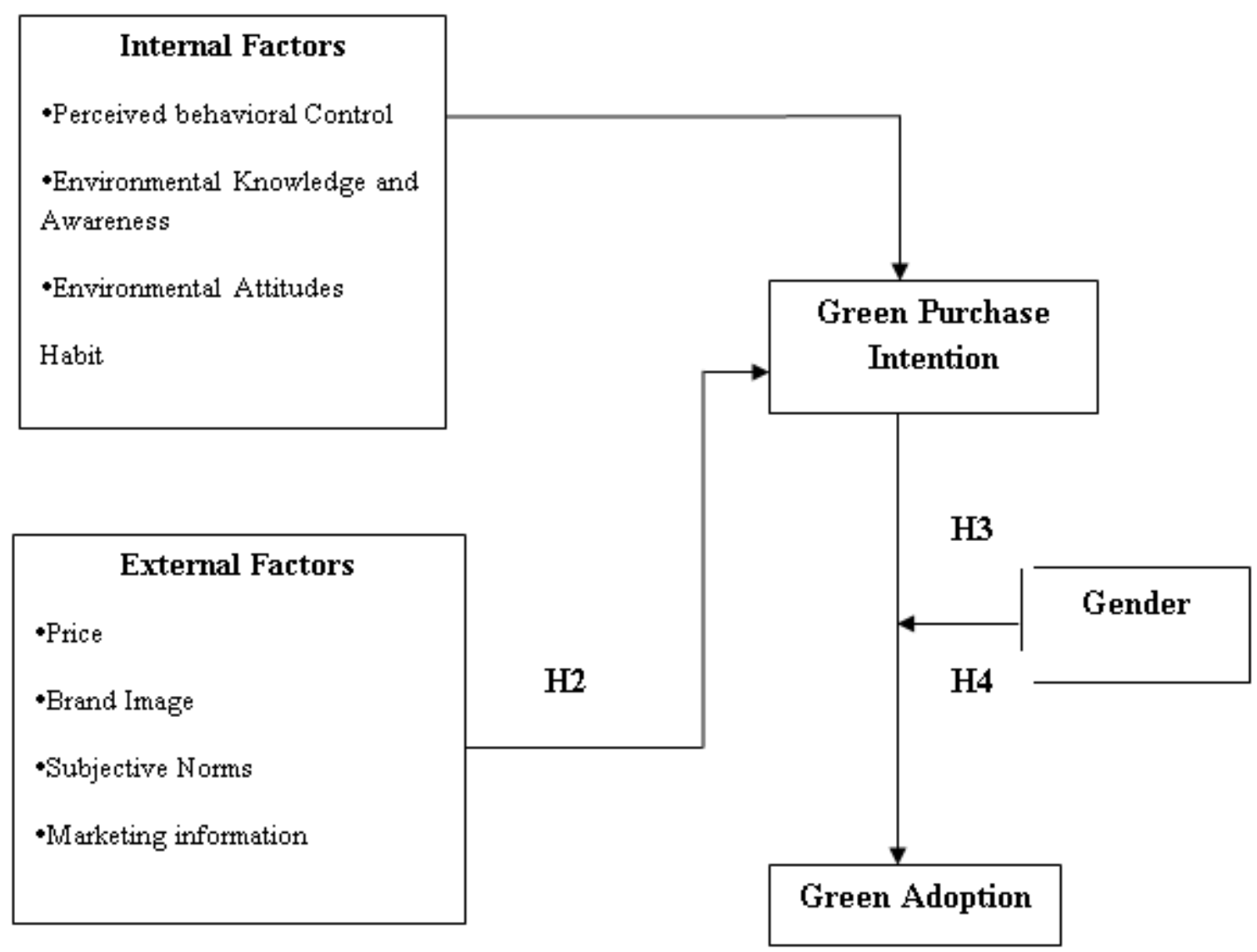

Figure 1. Integrated Model of Green Purchase Intention and Adoption

Based on the review of the literature, the variables of that incorporated in to TPB discuss in the following section.

\subsection{Literature and Methodology}

The purpose of literature review is twofold: Primarily it focuses on identifying the major factors/drivers impact on purchase intention and behavior by examine existing empirical research studies and the next, to determine the reasons which are influenced to widened the identified value-action gap of green products(green vehicles).

\subsection{Scope}

The present study reviewed the empirical articles of consumer green purchase behavior, including both green vehicles and other general green products articles which are published in reputed academic journals from year 2000-2017. The period (2000-2017) was selected because major previous studies which are published before year 2000 associated to green purchase behavior of general products and first green vehicle only introduced to the market in year 2000.Hence the previous studies are not much relevant.

Nevertheless, a review of previous studies included before 2000 explain the nature of the recent empirical literature. The present study concentrates on analyses that seek to 
acknowledge the different factors influencing the green purchase behavior of green vehicles and other general green products.

\subsection{Selection of Studies}

The study focuses on the different factors that could explain and impact on consumer purchase intention and actual behavior towards green vehicles and other general green products. For selection of relevant studies, some criteria have utilized.

1. The studies published during the period of year 2000 to 2017.

2. The studies which are empirical in nature.

3. The studies which have explained the factors which influence on green purchase intention and behavior.

Research articles which are published during the period of 2000-2017 identified through a logical approach that included searching of key words in the database title, abstract, and keyword. The several combination of key words have been used including "green purchase behavior", "Green vehicles", "Hybrid Electrical Vehicles", "eco- innovation adoption", "Green gap", "Value-action gap", "green purchasing", sustainable consumption behavior", "green consumption", "adoption to green vehicles". This examination was able to recognized 201 studies. According to content analysis of those studies conducted by cross checking the abstracts to make sure that the data base included only the relevant articles for the study. Then, only the studies which have examined factors, motives, and barriers influence on green products purchasing intention and behavior were selected and included, which altogether account for 126 studies and had to eliminate 75 studies. All articles were cross checked to eliminate duplication.

The studies are arranged in yearly order. The selected articles were limited in number as only empirical studies to green purchasing intention and behavior of Hybrid Electrical Vehicles were only included. The studies are arranged according to the year of publication. The only empirical articles were selected because of its less bias nature and its capability of representation of real consumer behavior in different contexts and cultures. The studies which are conducted in both developed and developing country (Europe, United States, Australia, Africa and Asia) context have included by enhancing the generalizability of the study.

\subsection{Approach of the Literature Analysis}

Kaushik \& Rahman, 2014; Salloum et al., 2011, suggested that literature review could done by using two types of analysis. They are within -study and between -study literature analyses. Hence as they suggested the present study applied both the method to analysis the literature. Within -study literature study analysis requires examining and reviewing of the entire content including title of the study, its literature review, conceptual framework, methodology, discussion, implications and future research direction. The analysis of information between two or more or even studies in order to disclose the similarities and difference between any of these studies in order to disclose the similarities and differences between any of these studies consider as the between-studies literature analysis. 
After the examination of some of integrated models, that external perspectives and based on the studies analyzed. It was revealed in the literature review that the internal influences referred to as individual factors (Sima, 2014; Joshi \& Rahman, 2015). These factors consist of variables that are associated with consumers' decision making and most of those are results of individual life and their experience (Joshi and Rahman, 2015).The situational factors are not results of consumers' own experience and they are uncontrollable to the consumers. These are the factors that include variables that explain range of different situations where the consumers have to make their decisions (Joshi and Rahman, 2015).

\subsubsection{Internal Factors}

With an extensive literature analysis the followings have identified as the major variables of internal variables. This component comprise of factors specifically related to personal decision making. These factors are typically due to personal experience and influence individual decision making (Joshi and Rahaman, 2015). As revealed the internal factors are one of the major construct which had examined by most of the green studies around the globe.

\subsubsection{Perceived Behavioral Control}

Ajzen (1991) defines perceived behavioral control as "the degree of ease or challenges presumed by a person in performing the behavior." It also refers to an individual's ability or capability to execute a specific task (Ajzen, 1988). Perceived consumer effectiveness and Personal moral norms also included under this category. Because these three terms refer how an individual believe that they could make a difference with their behavior. Perceived Consumer effectiveness is "the assessment by consumers of the degree to which their consumption can make different in the overall issue" (Webster, 1975).

Roberts (1996) has also described some attitudinal variables relating to the behavior of consumers that is environmentally concerned. One such variable is Perceived Consumer Effectiveness. This is the judgment of a consumer on his or her own ability to be influential on issues relating to environmental resources. Roberts (1996) also observed that conservatives are more worried about the environment than the others. He also states environmentally conscious is a way to demonstrate social responsibility.

Another extended element of the TPB model is personal moral norm. According to Beck and Ajzen (1991) this means that a person feels that he should perform a particular behavior due to a moral obligation and his judgment is based on his responsibility or principles.

A distinction between personal moral norm and the subjective norm has been identified. Subjective norm is linked to external social influence, whereas the personal moral norm is connected to values in a person. The key feature of the personal moral norm is the internalization. In the present study, the researches described personal moral norm as "a norm in which a customer determines to adopt or not based on their own personal responsibility instead of social pressure or social norm.

Gleim \& Lawson (2014) is of the view that the actions of consumers also depend on their 
personal norms. According to Schwartz (1977) personal norms are at the individual level and it is about how a particular person feels as to what to do in a particular situation. A consumer's decision making is related to his or her personal norms. It is formed as a part of the social norms around the consumer. And according to Miniard \& Cohen (1983) and Osterhus (1997) as individuals want to live in conformity with the social norms their actions often reflect the expectations of society. In the context of green purchasing, this is problematic as consumers would not influence others to make decisions in favor of environmental protection.

In another research carried out by Jansson, Marell \& Annika (2010) on the factors that influence consumers to adopt eco-innovation and early adoptions, it has been revealed that personal norms enhances the willingness to adopt eco-innovation whereas habit is a negative influence on this willingness.

Purchasing intentions and actual purchasing significantly influence by Perceived Behavioral Control. Seventeen studies which have undertaken to analyze for the present study reported significant association (e.g., Wang, 2014; Gleim and Lawson, 20014; Wang et al., 2014; Hong et al., 2013; Mostafa, 2006; Tan, 2011).Even though evidence are available on the importance of perceived behavioral control on intention and behavior, further empirical investigation is required due to limited research studies in the area of green vehicles.

\subsubsection{Environmental Knowledge and Awareness}

Knowledge was found to be the one of the most studied variable; sixteen studies which taken for the present study examined consumers' knowledge and awareness of green products. Out of these fifteen studies, fourteen studies recognized that knowledge and awareness of green products positively influenced on consumer intention and adoption to green products (e.g., Gleim, 2014; Karunnayake \& Wanninayake, 2015; Soon et al., 2013). Only one study reported that lack of knowledge on green products negatively influence on purchase intention. Bang et al. (2000) stated that several studies found that customer knowledge did not affect the purchase of fuel-efficient vehicles (Bang et al., 2000). Even though it is considered as time and effort consuming activity for searching information on products, consumers spend more time by searching information prior to purchase durable goods (e.g. electronics, vehicles). Hence there is a possibility of purchasing durable products (green purchase) because the consumers are spending more time and effort to studying new products available in the market (Gleim et al., 2013; Laurent \& Kapferer, 1985; Oliver \& Lee, 2010).

One of the most important predictors of environmental behavior is environmental knowledge and awareness (Grob, 1995; Gatersleben et al., 2002). Knowledge about both the acts and general concepts referring to the environment and ecosystems is regarded is regarded as the environmental awareness (Mostafa, 2007). This knowledge is also regarded as Eco-literacy (Laroche et al., 2001). Grob (1995) illustrates two main elements of awareness that are fact-based knowledge and acknowledgment of environmental issue to test more adequate eco-friendly behavior. According to Patel and Foster (2005), there is a huge crowd of consumers who are unaware of the environmental consequences of their behavior. It is because they are not adequately exposed to different green product communications created 
(Baker \& Ozaki, 2008). But, they want to have more details on eco-friendly procedures (Young et al., 2010). As per past studies, ecological knowledge and values appear to be more identical in explaining the attitudes of green consumers and especially consumer behavior (Bezencon \& Blili, 2010; Follows \& Jobber, 2000; Leonidou et al., 2010; Mostafa, 2007; Shaw \& Shiu, 2003).

The evolution of one's knowledge about the environment is two-fold. First, how far a consumer should be educated to understand how a particular product affects the environment. Secondly, the knowledge of the consumer that a particular product was produced in an environmentally-friendly way (D’Souza, Taghian, \& Lamb, 2006).

Environmental knowledge and awareness found to be one of the most studied variables. As per the analysis of previous studies there are sixteen studies deliberated this variable and identified different relationships with purchase intention and adoption to green behavior. Out of these studies fourteen studies reported environmental knowledge and awareness of environmental issues have had a positive impact on consumer intention and purchasing behavior of green products (e.g., Johnstone \& Tan, 2015; Lao, 2014). Two studies found no relationship between consumer environmental knowledge and green purchase intention (Chan \& Lan 2000). Environmental knowledge moderated the relationship between ecological attitude and green behavior, according to Fraj-Andrés et al. (2007). Furthermore, there is no significant relationship between environmental benefits and consumer buying behavior (Shepherd et. al., 2005; Sima, 2014).Samarsinghe 2012 identified no association in between knowledge of environmental benefits and knowledge and attitude toward green behavior. The above results recommended that environmental knowledge may have a relationship with purchase intention and green purchase behavior and a valid variable for further studies.

\subsubsection{Environmental Attitudes}

Lee (2008) claims that the environmental attitude is connected to the environmental protection value judgment of the people. Further, Kim \& Han (2010) stated that it is the "overall evaluation of the specific behavior" in TPB. De Medeiros \& Ribeiro (2017) described environmental attitude as "individual belief, affective and behavioral intention with regard to environmental practices and problems". In regard to the consumer's intention to adopt Hybrid vehicles, attitude is considered as the "favorable or unfavorable assessment of the adoption behavior" In relation to the intention of the consumers to adopt hybrid vehicles; attitude is the "positive or negative evaluation of the adoption behavior". Laroche, Bergeron \& Barbaro-Forleo (2001) explain about two main attitudes in relation to environmental behavior. These are importance and inconvenience. Importance because consumers will be concerned if they think that a particular environmental issue is important to them. Inconvenience plays a vital role as the level of inconvenience that a consumer has to go through when he adapts a new Laroche et al. (2001) is of the view that perceived level of responsibility is also another influential attitude. Here, consumers perceive that companies are not acting in a responsible manner towards environmental protection. According to Stern et al. (1999), in the context of understanding the green behavior of consumers, attitude is of vital importance. Many studies show that attitude is a really crucial posterior of behavioral 
intention (Kang et al., 2006; Dickinger \& Kleijnen, 2008). For example in his survey to find out the willingness of the consumers to pay for green vehicles, Hidrue et al. (2011) found that if a consumer has a positive attitude green vehicles, that customer is much more prepared to accept it. Beck and Ajzen (1991) also say that when the consumer's attitude is positive, they are more intended to perform a particular behavior.

Numerous researches (Kim \& Choi, 2005; Laskova, 2007; Laroche, Bergeron, \& BarberoForleo, 2001; Wahid, Sinnappan, \& Rahman, 2011) reveal that attitude play a vital role. However attitude of environment is based on two things namely, how consumers value the importance of environmental protection and their awareness about environmental issues (Wahid et al., 2011). Chen \& Chai (2010) say that if the consumers have this kind of attitude towards environment, they are more likely to combine environmental protection in their day-to-day lives. Also, these consumers are influenced by environmental problems to choose green products.

Stephen (2006) argue that consumers who use a car as s sign of wealth have an implication in trying to promote green vehicles. On the other hand, a study revealed that those who use a car as a sign of wealth may not annoy in its environmental impact. Aman et al. (2012) research findings pointed out that the attitude does have a partial mediating impact on the connection among concern for the environment and purchase intention.

According the literature analysis done, altogether nineteen studies investigated the possible relationship of attitudes, intention and adoption. All the studies have reported significant positive relationship between attitudes, intention and adoption (Lao, 2014; Johnstonem, 2015).

\subsubsection{Habit}

Research has been carried out to examine the factors of green curtailment behavior and consumer adoption of innovative products marketed as green (eco- innovations) as well as to examine factors illustrating these two types of green behavior. In the case of curtailment, the impact was negative suggesting that the earlier adoption reduces the readiness to use curtail cars. This study indicates that users of eco-innovation, in this case, the alternative fuel vehicle, are happy with their initial adoption decision and show a strong readiness to conform to that decision in future purchases (Jansson et al., 2010).

According to previous studies, consumers are hesitant to do extended cognitive processing or to search deeply for information. Petty \& Caccioppo (1986) suggest that this is why consumers continue to buy conventional products. Samuelson \& Zeckhauser (1988) argue that consumers are more comfortable with their usual previous behavior due to financial, emotions and time risk connected with novel products and behavior. For instance consumers are not foreseen the future benefits associated with the installation of Solar power system to their home, but they only concern the current cost and the difficulties of installation associated with it (Gleim \& Lawson, 2014). Further according to Kilbourne (1998) individuals are always try to maintain their status and really not bother about the cost associate with it in the long run and the negative influence of such act on the environment. 
Consuming the status quo and maintaining the behaviour is very efficient because it is a routine factor which can be done without thinking. (Gleim \& Lawson, 2014). Research suggests individuals are generally reluctant to conduct elaborate cognitive processing and extensive information search, thus it is not surprising that many individuals find it more convenient to continue purchasing conventional products (Petty \& Caccioppo, 1986).

According to the literature review two studies reported negative influence of habit on green behavior (Vermier \& Verbeke, 2006; Padel \& Foster, 2005). But habit or past experience of green products encouraged further green behavior (Claudy, 2011; Samarsinghe, 2012; kumar, 2015). Further habit has been reported as one of the most major barrier to adopt in to green products mainly due to comfort they experience with the conventional products.Habit and past experience considered as a factor which is difficult to change. Petty \& Caccioppo (1986) stated that consumers who are attached to conventional products are reluctant to change their purchase decision and behavior because they are still remaining loyal to those. The limited number of studies conducted on this encouraged for further investigation in relating to the green vehicles.

\subsubsection{External Factors}

A number of studies find a range of factors influencing on buying a car. According to Stephen (2006) some of the external influences include economic and regulatory conditions, fuel consumption and road infrastructure. Almost all studies which reviewed for the present study included external variables in their studies and examined the impact of external variables on consumer intention and behavior such as Product characteristics, subjective norms, marketing information and other environmental factors.

\subsubsection{Price}

According to Paulus (2002) price is still the main factor against buying hybrid vehicles. When studying green behavior, products attributes such as price also play a vital role. The consumers are price conscious when they adopt green behavior (D'Souza et al., 2007). Further, Young et al. (2010) is of the view that price acts as a barrier to green purchase behavior. This is because when a person wants to make a decision towards green values, price is a barrier against it. Indeed, Vlosky, Ozanne \& Fontenot (1999) stated that consumers those who are willing to pay extra for green products are the people who are concerned about the environment. Oliver et al. (2011) explained about the willingness of a consumer to pay a particular price and price perception is important when examining how price acts in relation to attitude and behavior. According to Laroche et al. (2001), the harm caused to the environment by ecological problems makes some customers pay a premium for green products. As per the study done by D'Souza et al. (2007) mentioned that if the consumer is a committed environmentalist, he is not bothered by the price factor in deciding to go green. However, Gatersleben et al. (2002) say that price is still a barrier for green behavior. They suggest solutions such as promotions, discounts, improved quality and product performance so that the products become credible and the consumers receive a value for their money. Further,green consumers are not as much of price sensitive as non-green consumers (Gleim et al., 2013; Van Doorm \& Verhoef 2011). But Gleim and Lawson (2014) suggest that with the 
present economic recession the most of consumers are very keen on their spending and compare the prices of competing products.

It has been reported in twenty two studies price is one of the variables which has strong relationship with green purchase behavior and cause to increase the green gap(Chang et al., 2008; Sharma, 2014; Irfan, 2014; Anvar, 2014). The three studies out of twenty two studies recognized price has a relationship with purchase intention (Karunanayake \& Wanninayake, 2015; Johnstone, 2014). The high prices of green products are discouraged the consumer intention and adoption.

\subsubsection{Brand Image}

"Brand is a name, phrase, emblem, design or all of the above, which is used to differentiate one's goods and services from rivals" (Kotler, 2000). Brand image is described as "perceptions of a brand expressed by the brand associations held in customer memory" (Keller, 1998).If customers are willing to buy products or services at a higher price, the brand image could contribute to a company's success Chin, Lai \& Tat (2018). Therefore, brand image is important for the future benefits of businesses such as long-term cash flow, decision-making, inventory cost, feasible competitive edge and market success (Torlak, 2014). Brand equity is about the value and satisfaction that inspire consumers to use a specific brand. It comprises feelings or attitudes about both the brand and quality (Lin, $\mathrm{Wu}, \&$ Chen, 2013).

The brand is the identification that identifies the product, service, and company, as per Abubakar et al. (2016). Brand images provide certain attributes or functions that illustrate the benefits of using a product or service (Lin et al., 2013). In addition, previous research found that brand image is positively connected to purchase intention (Charo et al., 2015). Yoo and Donthu (2001) also stated that brand image influences the profits of the company due to the high brand image of a product or service could lead customers to buy products or services even at higher prices. Jalilvand \& Samiei (2012) also observed that brand image impacts buying intention substantially.

\subsubsection{Subjective Norms}

The definition given for subjective norm by Ajzen (1991) is "the perceived social pressure of a person gets from other individuals or groups that are vital to him/her and they wish or expect him/her to conduct into a certain way." Social influence and subjective norm have almost the same meaning (Wahid et al., 2011). The other interpretation of social influence is provided by Rashotte (2007) as "the shift in the ideas, feelings, attitudes or behavior patterns of an individual resulting from interaction with another individual or group." Anyhow the idea of 'social influence' is "changing individual attitudes or behaviors through the influence of others."

According to Ohman (2011) a decision made by a buyer to select a green product is greatly influenced by social influence in that once a buyer has the intention to buy a green product, the social pressure leads him to put that intention into action. Social influence is made up of colleagues, loved ones, educators, workers, fellow employees, experts and media ( Klobas \& Clyde, 2001). Maram \& Kongsompong (2007) had similar opinion who says friends, family, 
associates, salespeople and even strangers can be influential. Axsen et al. (2009) state that social interaction and societal trends also influence consumers to purchase hybrid cars. Further he explained that several people would follow the group's trend or direction whenever they want to take decisions. Han et al. (2010) stated that consumer would act thinking about would act thinking about whether their referent would approve or disapprove of such behavior. The one that more closer to the consumer could able to change the purchase decision of the even at the last moment (e.g., Gupta, 2009).

Altogether thirty five studies have examined the influence of subjective norms/social influence on purchase behavior. Of such, twenty three studies showed subjective norms have a positive association with purchase intention and adoption to green products (e.g.Gleim, 2014; Anvar \& Venter, 2014) and two studies showed that societal norm had a negative association with purchase intention and actual purchasing behavior (e.g; Connell, 2010; Lee, 2011). Subjective norm also was observed have an indirect impact on customer green buying behavior while it affected green attitudes which influenced green buying behavior (Gadenne et al., 2013). Therefore, It can be concluded that subjective norm has significance association with consumer buying behavior. Among these thirty five studies reference groups such as family, peers, and neighborhood influence on purchase intention and adoption were recognized (Ozaki \& Sevastyanova, 2010; Khare, 2014). All these studies reported positive relationship among reference group, intention and adoption. Research results further reveal that especially peers and other persons with close proximity to consumers have a stronger impact on the green purchase decision of customers (Gupta, 2009; Chang et al., 2015).

\subsubsection{Marketing Information}

Consumers collect information about a product before purchasing it. They do this even when they intend to buy a certain product in the future. According to Olshavsky \& Wymer (1995) and Hung \& Cheng (2013) there are various sources of information they can rely on. They are information control by marketers such as advertising, product brochures, Service providers' information such as reseller catalogues, Third party independent institutes publications as such as newspaper and magazine articles, interpersonal sources from friends and by doing a direct inspections. Many researches explored the different phases of the Consumer Decision Making Process (CDP) model with respect to consumer green purchasing. According to Bloch et al. (1986) the first step is about getting to know the problems relating to purchasing. If the consumers have higher awareness at this stage, they can make better decisions in favor of green purchase behavior. Details regarding CDP can be searched internally or externally. Baker \& Ozaki (2008) say that in the context of green consumption, information gathered from internal sources like the feelings of consumers and their past experience is very limited. As such, if comprehensive details regarding green consumers are sought, external sources are the best method. Byron (2005) says that once the information is gathered, consumers will weigh their choices prior to the purchasing. What they choose ultimately is what brings a solution to their problem.

Baker and Ozaki (2008) believe that one of the reason for niche green markets and a smaller number of green products is the fact that mass media do not use reference groups in their 
advertising. Green marketing should now go beyond traditional media towards social media. According to writers such as Fraser (2011) and Wenzel (2009) the as the interest in concept such as climate change, sustainability and going green has increased, it has resulted in an 'explosion of interest' in online social media. Gunther (2012) says that new technology such as smart phones and social networking are being used by a large number of companies and non-profit organizations to promote green products with the buyers.

Li (2013), an eco-blogger discusses the concept of 'Green web' and how the use of internet and social media has been increasing fast vis-à-vis taking part in environmental causes. She says that an internet connection is the only thing someone needs to get together and support an issue such as climate change or clean energy. Li also emphasizes the importance of choosing the correct online community among all the 'green social networks' to promote an issue.

Analyzing how green websites function, Pierobon (2012) states that most of the websites and blogs direct their readers to selected web sites they like to promote. The writer also describes how certain green web sites are closed down when their political agendas not fulfilled. (Willaims et al., 2014).

Fourteen studies which have taken for the present study revealed that availability of sufficient amount of information support the adoption to green products and source of information also consider as the crucial factor to enhance the green gap (e.g., Lane \& Stephen, 2007; Coad et al., 2009). All the studies reported positive relationship in between external information and adoption to green products. There are twelve studies explained the importance and role of social media, green labels and advertising appeal to make consumer aware about environmental consequence, their responsibility and encourage them to adopt in to green products (e.g., Williams, 2012; Chen, 2013). These studies have recognized positive relationship in between Social media, advertising appeal and intention/adoption to green products (e.g., Sima, 2014; Irfan, Sumanggala, \& D'souza, 2014). The limited availability of very recent studies on external information encourages further studies on it.

\subsubsection{Gender}

Studies also investigated the connection between consumer demographics and their Green Consumer behavior. Gender and green purchase association results are also mixed. Some found a higher proportion of women buying organic food products (Cheng et al., 2002; Cheng \& Yang, 2001; Zeng et al., 2007), whereas men are the influential buyers of green building materials (China Environment Federation, 2009). In China, women are generally responsible for cooking and buying food, whereas men are responsible for building houses and thus buying building materials. As such, the connections noted may not necessarily imply a distinct gender-green product purchase interaction. Gender, on the other hand, has no influence on the purchase of green products in the Malaysian context.

Only a few studies examined the moderating effect of ethnic group on green purchase intention. Sinnappan \& Rahman (2011) investigated the factors influencing green buying behaviors as well as the role of ethnic group, age, and educational level, type of education, 
gender and level of income towards green buying behavior among Malaysian customers. The finding implied that in the case of green purchases, the role of ethnic gender is not important among Malaysian consumers.

Marketers have identified a gender-based difference in buying behavior. Researchers examined gender differences in direct marketing, catalog shopping, brick-and-mortar shopping. Stem investigated the use of male / female financial media in 1988. Surveys suggest that both men and women don't trust the media and advertising as a source of financial information. There are still differences between the use of media by male and female. Eastlick \& Lotz (2001) researched catalog shopping motives among male and female. It was discovered that Salient male patronage motives for catalog mainly consisted of merchandise and service-related motives. In contradistinction, females stated that their pertinent motives were convenience-oriented.

Therefore based on the literature this study builds upon prior research on ecommerce (Zhang $\&$ Prybutok, 2005) and explores the moderating effect of gender in between internal, external factors and consumer adoption.

\section{Discussion and Conclusion}

Many contradictory and competing variables mold the daily choices and decisions of consumers. Likewise, there are many factors influencing the decisions of consumers towards green behavior adoption that have not been elucidated on. Based on the TPB and selecting the most important and widely discussed factors in previous studies (both in green vehicles and other general products) the extended research model has developed. But some factors have omitted due to least application of those factors in previous green vehicles studies such as health consciousness, shopping style, living arrangement, economic constraints.

Several other social psychological theories and frameworks have been formed to illustrate the gap between consumer attitude and behavior; i.e. Ajzen's Theory of Planned Behavior (1991); Ajzen \& Fishbein (1980); Reasoned Action Theory (TRA); Schwartz's Value Theory (1992) and his Norm-Activation Theory (1997); Stern's Value-Belief-Norm (VBN) Theory (2000). These models explain the intent and impact of the green consumer behavioral intention towards the actual green behavior. Most empirical research used the "Theory of Planned Behavior" and the "Theory of Reason Action" which conceptualize intention as one of the most immediately relevant indicators of the corresponding behavior. Thus, this study attempts to address this shortcoming by mainly applying ' The Theory of Planned Behavior ' to analyze consumer green attitude-behavior gap with alteration of major factor influence on behavioral intention to develop the conceptual framework.

As with Ajzen (1991), the present study attribute a direct relationship with intention and adoption to green behavior has included, but the moderating effect of gender has introduced based on Kollmuss \& Agyeman (2002), Internal factors (Perceived behavioral control, environmental knowledge and awareness, environmental attitudes and habit) together with external factors (price, brand image, subjective norms and marketing information) make up a 
complex 'adoption to green behavior". In turn, this complex is integrated into broader internal and external factors. It could be argued that subjective norms should be seen as a distinct group overlap with internal and external factors. It is considered that even if the present model were to vary at various stages in people's lives and based on the product type and service, and present study agreed that it would not, but that the multiple factors underlying in it, and the synergies between them, would play larger or smaller roles during the development process.

The arrows in Figure 1 show how the various factors impact one another and, eventually, green behavior adoption. Most of them are self-explanatory. Gender implies probable obstacles to the positive impact on green behavior adoption.

It is apparent that although all theories and models addressing the green attitude-behavior (value-action) gap have added distinct perspectives to explain the issue, these insights have not yet been investigated in a single purified/integrated model to anticipate green behavior in a much more comprehensive way. Thus, the present conceptual framework of the study addresses this limitation by developing a more extensive conceptual model that attempts to connect all major contributions of conceptualizations based on past literature. It underlines the study's improved theoretical rigor and Figure 1 shows the conceptual model and each section explains these contributions by developing hypotheses or proposals for study. Further most of the cited studies have studied how consumers' social-economic, demographic and psychological characters correlate to their green consumption behavior. Systematic research effort to study consumers' intention and adoption to green products has been lacking in Sri Lanka. The major factors affecting consumer adoption to green vehicles behavior intention in the country context and not yet explored empirically. As such, present study represents a first step toward mending such research gap in Sri Lanka.

Therefore, based on the literature review, the following conceptual model was developed featuring the hypothetical relationships that take place the study's independent variables and dependent variable. Conceptual framework comprises of two constructs; internal factors and external factors and their variables namely perceived behavioral control, environmental attitude, environmental knowledge and awareness, habit, price, brand image, subjective norms and marketing information. Green consumer behavior intention is the mediator while gender moderates the green purchasing behavior is the dependent variable.

Finally, it can be stated that this new extensive study framework will promote multi-faceted research on green consumer behavior in the empirical domain. This has remained unexplored in the literature on green and consumer behavior.

\section{References}

Abou-Zeid, M., \& Ben-Akiva, M. (2011). The effect of social comparisons on commute well-being. Transp. Res. Part A, 45(4), 345-361. https://doi.org/10.1016/j.tra.2011.01.011 
Abubakar, A. M., llkan, M., \& Sahin, P. (2016). eWOM, eReferral and gender in the virtual community. Marketing Intelligence \& Planning, 34(5), 692-710. https://doi.org/10.1108/MIP-05-2015-0090

Aertsens, J., Verbeke, W., Mondelaers, K., \& Van Huylenbroeck, G. (2009). Personal determinants for organic food consumption: a review. British Food Journal, 111, 1140-1167. https://doi.org/10.1108/00070700910992961

Afuah, A. (2002). Mapping technological capabilities into product markets and competitive advantage - The case of cholesterol drugs. Strategic Management Journal, 23, 171-179. https://doi.org/10.1002/smj.221

Ajzen, I., \& Fishbein, M. (1980). Understanding attitudes and predicting social behaviour. Prentice-Hall, Englewood Cliffs, NJ: Prentice-Hall.

Ajzen, I. (1988). Attitudes, personality and behavior. Dorsey, Chicago, IL.

Ajzen, I. (1991). The theory of planned behavior. Organizational Behavior and Human Decision Processes, 50(2), 179-211. https://doi.org/10.1016/0749-5978(91)90020-T

Aman, A. H. L., Harun, A., \& Hussein, Z. (2012). The influence of environmental knowledge and concern on green purchase intention the role of attitude as a mediating variable. British Journal of Art and Social Sciences, 7(2), 145-167.

Anvar, M., \& Venter, M. (2014). Attitudes \& purchase behaviour of green products among generation Y consumers in South Africa. Mediterranean Journal of Social Sciences, 5, 183-194. https://doi.org/10.5901/mjss.2014.v5n21p183

Arvola, A. (2008). Predicting intentions to purchase organic food: The role of affective and moral attitudes in the Theory of Planned Behaviour. Appetite, 50(2-3), 443-454. https://doi.org/10.1016/j.appet.2007.09.010

Axsen, J., Mountain, D. C., \& Jaccard, M. (2009). Combining stated and revealed choice research to simulate the neighbor effect: The case of hybrid-electric vehicles. Resource and Energy Economic, 31, 221-238. https://doi.org/10.1016/j.reseneeco.2009.02.001

Bagozzi, R. P., Yi, Y., \& Baumgartner, J. (1990). The level of effort required for behaviour as a moderator of the attitude-behaviour relation. European Journal of Social Psychology, 20(1), 45-59. https://doi.org/10.1002/ejsp.2420200105

Baker, J., \& Ozaki, R. (2008). Pro-environmental products: marketing influence on consumer purchase decision. Journal of Consumer Marketing, 25(5), 281-293. https://doi.org/10.1108/07363760810890516

Bamberg, S. (2003). How does environmental concern influence specific environmentally related behaviors? A new answer to an old question. Journal of Environmental Psychology, 23(1), 21-32. https://doi.org/10.1016/S0272-4944(02)00078-6

Bang, H., Ellinger, A. E., Hadjimarcou, J., \& Traichal, P. A. (2000). Consumer concern, knowledge, belief, and attitude toward renewable energy: an application of the reasoned 


\section{Macrothink}

Journal of Sociological Research

ISSN 1948-5468

2019, Vol. 10, No. 2

action theory. Psychology and Marketing, 17(1), 6-26. https://doi.org/10.1002/(SICI)1520-6793(200006)17:6\%3C449::AID-MAR2\%3E3.0.CO ;2-8

Bezencon, V., \& Blili, S. (2010). Ethical products and consumer involvement: What's New? European Journal of Marketing, 44(9/10), 1305-1321. https://doi.org/10.1108/03090561011062853

Bloch, P. H., Ridgway, N. M., \& Sherrell, D. L. (1989). Extending the concept of shopping: an investigation of browsing activity. J. Acad. Mark. Sci., 17(1), 13-21. https://doi.org/10.1007/BF02726349

Byrd, K. S., \& B. S. Caldwell. (2011). Increased memory load during task completion when procedures are presented on mobile screens. Behaviour \& Information Technology, 30(5), 643-658. https://doi.org/10.1080/0144929X.2010.529944

Byron, E. (2005). New Penny Chain: Goes For 'Missing Middle'. The Wall Street Journal, 68-97.

Chan, R.Y. K., \& Lau, L. B. Y. (2000). Explaining green purchasing behavior. Journal of International Consumer Marketing, 14(2), 9-40. https://doi.org/10.1300/J046v14n02_02

Chang, H. H., \& Chen, S.W. (2008). The impact of online store environment cues on purchase intention: trust and perceived risk as a mediator. Online Information Review, 32(6), 818-41. https://doi.org/10.1108/14684520810923953

Chang, C. C., Tsai, J. M., Hung, S. W., \& Lin, B. C. (2015). A Hybrid Decision Making Model for Factors Influencing the Purchase Intention of Technology Products: The Moderating Effect of Lifestyle. Behavior \& Information Technology, 34, 1200-1214. https://doi.org/10.1080/0144929X.2015.1019566

Chen, T. B., \& Chai, L. T. (2010). Attitude towards the environment and green products: Consumers' perspective. Management science and engineering, 4(2), 27-39.

Chen, M. F., \& Tung, P. J. (2010). The moderating effect of perceived lack of facilities on consumers' recycling intentions. Environmental Behavior, 42(6), 824-844. https://doi.org/10.1177/0013916509352833

Chen, Y. (2013). Towards green loyalty: Driving from green perceived value, green satisfaction, and green trust. Sustainable Development, 21(5), 294-308. https://doi.org/10.1002/sd.500

Cheng, H., Yang, R., Li, K., \& Zhu, Q. (2002). An analysis on the factors influencing China's green consumption. China Business and Market, 16(4), 35-38.

Cheng, H., \& Yang, R. (2001). The characteristics and composition of green consumption the inspiration from a survey of green consumers in Beijing. Consumer Economics, 17(4), 9-10.

Chin, T. A., Lai L. Y., \& Tat, H. H. (2018). Determinant of brand image and their impact on 
purchase Intention of Grab. Journal of Arts and Social Sciences, 2(1).

China Environment Federation. (2009). Green survey. Retrieved June 206, from http://green.sohu.com/ 20090508/n263844187

Claudy, M. C., Michelsen, C., \& O`Driscoll, A. (2011). The diffusion of microgeneration technologies - assessing the influence of perceived product characteristics on home owners' willingness to pay. Energy Policy, 39(3), 1459-69. https://doi.org/10.1016/j.enpol.2010.12.018

Coad, A., Haan, P. D., \& Woersdorfer, J. S. (2009). Consumer Support for Environmental Policies: An Application to Purchase of Green cars. Ecological Economics, 68, 2078-2086. https://doi.org/10.1016/j.ecolecon.2009.01.015

Connell, K. Y. H. (2010). International external barriers to coconscious apparel acquisition. International Journal of Consumer Studies, 34(3), 279-286. https://doi.org/10.1111/j.1470-6431.2010.00865.x

Corraliza, J. A., \& Berenguer, J. (2000). Environmental values, beliefs and actions: a situational approach. Environment and Behaviour, 32(6), 832-848. https://doi.org/10.1177/00139160021972829

De Medeiros, J. F., \& Ribeiro, J. L. D. (2017). Environmentally sustainable innovation: Expected attributes in the purchase of green products. J. Clean. Production, 142, 240-248. https://doi.org/10.1016/j.jclepro.2016.07.191

Deng, G., \& Liu, Y. (2011). Low carbon consumption and transformation of Chinese consumers consumption patterns. Consumer Economics, 27(3), 59-62.

Dholakia, U. M. (2001). A motivational process model of product involvement and consumer risk perception. European Journal of Marketing, 35(11/12), 1340-60. https://doi.org/10.1108/EUM0000000006479

Dickinger, A., \& Kleijnen, M. (2008). Coupons going wireless: determinants of consumer intention to redeem mobile coupons. J. Interact. Mark., 22(3), 23-39. https://doi.org/10.1002/dir.20115

Dobscha, S., \& Ozanne, J. L. (2001). An eco-feminist analysis of environmentally sensitive women using qualitative methodology: the emancipatory potential of an ecological life. Journal of Public Policy \& Marketing, 20(2), 201-214. https://doi.org/10.1509/jppm.20.2.201.17360

D’Souza, C., Taghian, M., \& Lamb, P. (2006). An empirical study on the influence of environmental labels on consumers. Corporate Communications. An International Journal, 11, 162-173. https://doi.org/10.1108/13563280610661697

D’Souza, C., Taghian, M., \& Khosla, R. (2007). Examination of environmental beliefs and its impact on the influence of price, quality and demographic characteristics with respect to green purchase intention. Journal of Targeting, Measurement and Analysis for 
Marketing, 15(2), 69-78. https://doi.org/10.1057/palgrave.jt.5750039

Eastlick, M. A., \& Lotz, S. (2011). Cognitive and institutional predictors of initial trust toward an online retailer. International Journal of Retail \& Distribution Management, 39(4), 234-255. https://doi.org/10.1108/09590551111117527

Fishbein, M., \& Ajzen, I. (1975). Belief, attitude, intention and behavior: an introduction to theory and research reading. MA: Addison-Wesley.

Fishbein, M., \& Cappella, J. N. (2006). The role of theory in developing effective health communications. Journal of Communication, 56, S1-S17. https://doi.org/10.1111/j.1460-2466.2006.00280.x

Follows, S. B., \& Jobber, D. (2000). Environmentally responsible purchase behavior: a test of a consumer model. European Journal of Marketing, 34(5/6), 723-746. https://doi.org/10.1108/03090560010322009

Fraj-Andres, E., \& Martinez-Salinas, E. (2007). Impact of environmental knowledge on ecological consumer behavior: an empirical analysis. Journal of International Consumer Marketing, 19(3), 73-102. https://doi.org/10.1300/J046v19n03_05

Fraser, C. (2011). Tapping social media's potential to muster a vast green army. Retrieved April 24, 2016 from http://e360.yale.edu/feature/tapping

Frey, B., \& Jegen, R. (2001). Motivation crowding theory. Journal of Economic Surveys, 15(5), 589-611. https://doi.org/10.1111/1467-6419.00150

Gadenne, D., Sharma, B., Kerr, D., \& smith, T. (2011). The influence of consumers' environmental beliefs and attitudes on energy saving behaviors. Energy Policy, 39(12), 7684-7694. https://doi.org/10.1016/j.enpol.2011.09.002

Gatersleben, B., Steg, L., \& Vlek, C. (2002). Measurement and determinants of environmentally significant consumer behavior. Environment and Behavior, 34(3), 335-62. https://doi.org/10.1177/0013916502034003004

Gleim, M., \& Lawson, S. J. (2014). Spanning the gap: an examination of the factors leading to the green gap. Journal of Consumer Marketing, 31(6/7), 503-514. https://doi.org/10.1108/JCM-05-2014-0988

Grob, A. (1995). A structural model of environmental attitudes and behavior. Journal of Environmental Psychology, $\quad$ 15(3), 209-20. https://doi.org/10.1016/0272-4944(95)90004-7

Guagnano, G., Stern, P., \& Dietz, T. (1995). Influences on Attitude Behaviour Relationships a natural experiment with curb side recycling. Environment and Behaviour, 27(5), 699-718. https://doi.org/10.1177/0013916595275005

Gunther, M. (2012). Betting on technology to help turn consumers green. Retrieved April 26, 2017, from http://e360.yale.edu/feature/betting. 
Gupta, S., \& Ogden, D. T. (2009). To buy or not to buy? A social dilemma perspective on green buying. Journal of Consumer Marketing, 26(6), 376-391. https://doi.org/10.1108/07363760910988201

Guru, C., \& Ranchhod, A. (2005). International green Marketing: a comparative study of British and Romanian firms. International Marketing Review, 22(5), 547-61. https://doi.org/10.1108/02651330510624381

Haeger, J. W., \& K. Storchmann. (2006). Prices of American Pinot Noir Wines: Climate, Craftsmanship, Critics. Agricultural Economics, 35, 67-78. https://doi.org/10.1111/j.1574-0862.2006.00140.x

Han, H., Hsu, L., \& Sheu, C. (2010). Application of the theory of planned behaviour to green hotel choice: testing the effect of environmental friendly activities. Tourism Management, 31(3), 325-334. https://doi.org/10.1016/j.tourman.2009.03.013

Harland, P., Staats, H. J., \& Wilke, H. A. M. (2007). Situational and personality factors as direct or personnel norm mediated predictors of pro-environmental behaviour: Question derived from norm-activation theory. Basic and Applied Social Psychology, 29, 323-334. https://doi.org/10.1080/01973530701665058

Hidrue, M. K., Parsons, G. R., Kempton, W., \& Gardner, M. P. (2011). Willingness to pay for electric vehicles and their attributes. Resour. Energy Econ., 33(3), 686-705. https://doi.org/10.1016/j.reseneeco.2011.02.002

Hines, J. M., Hungerford, H. R., \& Tomera, A. N. (1987). Analysis and synthesis of research on responsible environmental behavior: A meta-analysis. The Journal of environmental education, 18(2), 1-8. https://doi.org/10.1080/00958964.1987.9943482

Homer, P. M., \& Kahle, L. R. (1988). A structural equation test of the value-attitude-behavior hierarchy. Journal of Personality and social Psychology, 54(4), 638. https://doi.org/10.1037/0022-3514.54.4.638

Hung, S. W., \& M. J. Cheng. (2013). Are You Ready for Knowledge Sharing? An Empirical Study of Virtual Communities. Computers \& Education, 62, 8-17. https://doi.org/10.1016/j.compedu.2012.09.017

Hopper, J. R., \& Nielsen, J. M. (1991). Recycling as altruistic behavior: Normative and behavioral strategies to expand participation in a community recycling program. Environment and Behavior, 23, 195-220. https://doi.org/10.1177/0013916591232004

Irfan, M., Sumangala, C., \& D' Souza, L. (2014). Green Marketing mix Strategies of Consumer durables with Refernce to Automobile Sector. International Journal of Engineering Research in Management \& Technology, 3, 56-60.

Jackson, T. (2005). Motivating sustainable consumption: a review of evidence on consumer behaviour and behavioural change", University of Surrey, Guildford, Retrieved on May 2016 from, www.c2p2online.com/documents/MotivatingSC.pdf. 
Jalilvand, M. R., \& Samiei, N. (2012). The effect of electronic word of mouth on brand image and purchase intention. Marketing Intelligence \& Planning, 30(4), 1-11. https://doi.org/10.1108/02634501211231946

Jansson, J., Marell, A., \& Annika, N. (2010). Green Consumer behaviour: Determinants of Curtailment \& Eco Innovation Adoption. Journal of Consumer Marketing, 27(4), 358-370. https://doi.org/10.1108/07363761011052396

Johansson, M. (1993). A Behavioural Science Framework for Regulating Household Waste Separation (in Danish). Aarhus: Aarhus Business School, Department of Marketing, Doctoral Dissertation.

Johnstone, M., \& Tan, L. P. (2015). An Exploration of Environmentally Conscious Consumers and the reason Why They do not Buy Green Products. Marketing Intelligence and Planning, 33, 804-825. https://doi.org/10.1108/MIP-09-2013-0159

Johri, L. M., \& Sahasakmontri, K. (1998). Green marketing of cosmetics and toiletries in Thailand. Journal of Consumer Marketing, 15(3), 265-8. https://doi.org/10.1108/07363769810219134

Joshi, Y., \& Rahaman, Z. (2015). Factors affecting green purchase Behaviour and Future research Directions. International Strategic Management Review, 3, 128-143. https://doi.org/10.1016/j.ism.2015.04.001

Kaiser, F. G., Wolfing, S., \& Fuhrer, U. (1999). Environmental attitude and ecological behaviour. Journal of Environmental Psychology, 19(1), 1-19. https://doi.org/10.1006/jevp.1998.0107

Kaiser, F. G., \& Scheuthle, H. (2003). Two challenges to a moral extension of the theory of planned behaviour: moral norms and just world beliefs in conservationism. Personal. Individ. Differ., 35(5), 1033-1048. https://doi.org/10.1016/S0191-8869(02)00316-1

Kalafatis, S. P., Pollard, M., East, R., \& Tsogas, M. H. (1999). Green marketing and Ajzen's theory of planned behaviour: a cross-market examination. Journal of Consumer Marketing, 16(5), 441-460. https://doi.org/10.1108/07363769910289550

Kang, H., Hahn, M., Fortin, D. R., Hyun, Y. J., \& Eom, Y. (2006). Effects of perceived behavioral control on the consumer usage intention of e-coupons. Psychol. Mark., 23, 841-864. https://doi.org/10.1002/mar.20136

Karunanayake, R. K. T., \& Wanninayake, W. M. C. B. (2015). Impact of Key Purchasing Determinants on Purchase Intention of Hybrid Vehicle Brands in Sri Lanka, an Empirical Study. Journal of Marketing Management, 3(1), 40-52. https://doi.org/10.15640/jmm.v3n1a4

Kaushik, A. K., \& Rahman, Z. (2014). Perspectives and Dimensions of Consumer Innovativeness: A Literature Review and Future Agenda. Journal of International Consumer Marketing, 26(3), 239-263. https://doi.org/10.1080/08961530.2014.893150 
Kawitkar, S. S. (2013). Impact of eco-friendly products on consumer behavior. International Indexed \& Refereed Research Journal, 40, 42-44.

Keller, K. L. (1998). Strategic Brand Management (2nd ed.). New Jersey: Prentice Hall.

Khare, A. (2013). Consumers' Susceptibility to Interpersonal Influence as a Determining Factor of Ecologically Conscious Behaviour. Marketing Intelligence \& planning, 32, 2-20. https://doi.org/10.1108/MIP-04-2013-0062

Kilbourne, W. E., \& Beckmann, S. C. (1998). Review and critical assessment of research marketing and the environment. Journal of Marketing Management, 14(6), 513-532. https://doi.org/10.1362/026725798784867716

Kilbourne, W. E, \& Pickett, G. (2008). How materialism affects environmental beliefs, concern, and environmentally responsible behaviour. Journal of Business Research, 61(9), 885-893. https://doi.org/10.1016/j.jbusres.2007.09.016

Kim, Y., \& Choi, S. M. (2005). Antecedents of green purchase behaviour: an examination of collectivism, environ- mental concern, and PCE. Advanced Consumer Research, 32, 592-599.

Kim, Y., \& Han, H. (2010). Intention to pay conventional-hotel prices at a green hotel a modification of the theory of planned behaviour. J. Sustain. Tour., 18(8), 997-1014. https://doi.org/10.1080/09669582.2010.490300

Kim, H. Y., \& Chung, J. E. (2011). Consumer purchase intention for organic personal care products. Journal of Consumer Marketing, 28(1), 40-47. https://doi.org/10.1108/07363761111101930

Klobas, J. E., \& Clyde, L. A. (2001). Social influence and internet use. Library Management, 22(1), 61-68. https://doi.org/10.1108/01435120110358943

Klockner, C. A., Nayum, A., \& Mehmetoglu, M. (2013). Positive and negative spill over effects from electric car purchase to car use. Transp. Res. Part D, 21, 32-38. https://doi.org/10.1016/j.trd.2013.02.007

Kok, G., \& Siero, S. (1985). Tin Recycling: awareness, comprehension, attitude, intention and behaviour. Journal of Economic Psychology, 6, 157-173. https://doi.org/10.1016/0167-4870(85)90019-4

Kollmuss, A., \& Agyeman, J. (2002). Mind the Gap: Why do people act environmentally \& What are the barriers to Pro-environmental behaviour. Environmental Education Research, 8(3), 239-255. https://doi.org/10.1080/13504620220145401

Kotler, P. (2000). Marketing Management (10th ed.). New Jersey: Prentice-Hall, Inc, A Pearson Education Company.

Kotler, P., \& Armstrong, G. (2013). Principles of Marketing (15th ed.). Global Edition, Pearson. 
Kumar, B. (2012). Theory of Planned Behavior Approach to Understand the Purchasing Behavior for Environmentally Sustainable Products. India. Research and Publication.

Lane, B., \& Stephen, P. (2007). The Adoption of cleaner vehicles in the UK: exploring the consumer attitude-action gap. Journal of Cleaner Production, 15, 1085-1092. https://doi.org/10.1016/j.jclepro.2006.05.026

Lao, K. (2014). Research on Mechanism of Consumer Innovativeness Influencing Green Consumption Behavior. Nakai Business Review International, 5, 211-224. https://doi.org/10.1108/NBRI-11-2013-0041

Laroche, M., Bergeron, J., \& Barbaro-Forleo, G. (2001). Targeting consumers who are willing to pay more for environmentally friendly products. Journal of Consumer Marketing, 18(6), 503-520. https://doi.org/10.1108/EUM0000000006155

Laskova, A. (2007). Perceived consumer effectiveness and environmental concerns. Proceedings of the 13th Asia Pacific Management Conference, Australia, 15, 206-209. https://doi.org/10.1016/S1441-3582(07)70026-5

Laurent, G., \& Kapferer, J. N. (1985). Measuring Consumer Involvement Profiles. Journal of Marketing Research (JMR), 22(1), 41-53. https://doi.org/10.1177/002224378502200104

Lee, K. (2008). Opportunities for green marketing: young consumers. Marketing intelligence \& planning, 26(6), 573-586. https://doi.org/10.1108/02634500810902839

Lee, K. (2011). The green purchase behavior of Hong Kong young consumers: the role of peer influence, local environmental involvement, and concrete environmental knowledge. Journal of International Consumer Marketing, 23(1), 21-44. https://doi.org/10.1080/08961530.2011.524575

Lee, K., \& Lee, K. (2012). Opportunities for green marketing young consumers. Marketing Intelligence \& Planning, 26(6), 573-586. http://doi.org/10.1108/02634500810902839

Leonidou, L. C., Leonidou, C. N., \& Kvasova, O. (2010). Antecedents and Outcomes of Consumer Environmentally-Friendly Attitudes and Behavior. Journal of Marketing Management, 26(13), 1319-1344. https://doi.org/10.1080/0267257X.2010.523710

Lee, K. (2009). Gender differences in Hong Kong adolescent consumers' green purchasing behavior. Journal of Consumer Marketing, 26(2), 87-96. https://doi.org/10.1108/07363760910940456

Li, L. (2013). 10 best green social networks. lornali.com. Retrieved April 24, 2016, from http://lornali.com/10-best-green-social-networks/.

Lin, C., Wu, Y., \& Chen, J. V. (2013). Electronic word-of-mouth: The moderating roles of product involvement and brand image. Technology Innovation and Industrial Management, 29-47.

Li, J. J., \& Su, C. (2007). How face influences consumption: a Comparative study of American and Chinese consumers. International Journal of Marketing Research, 49(2), 
237-56. https://doi.org/10.1177/147078530704900207

Li, P. (2011). Analysis of the structure of low carbon consumption. Consumer Economics, 27(4), 15-18.

Loureiro, M. L., McCluskey, J. J., \& Mittelhammer, R. C. (2002). Will consumers pay a premium for eco-labeled apples? Journal of Consumer Affairs, 36(2), 203-219. https://doi.org/10.1111/j.1745-6606.2002.tb00430.x

Luo, C. (2010). Influencing factors analysis of consumers' willingness to pay for safe food. China Rural Survey, 6, 22-34.

Luzar, E. J., \& Diagne, A. (1999). Participation in the next generation of agriculture conservation programs: the role of environmental attitudes. Journal of Socio-Economics, 28, 335-349. https://doi.org/10.1016/S1053-5357(99)00021-9

Maram, H. K., \& Kongsompong, K. (2007). The power of social influence: East-West comparison on purchasing behavior. International Marketing Conference on Marketing \& Society, 649-655.

Martinsons, M. G., So, S. K. K., Tin, C., \& Wong, D. (1997). Hong Kong and China: emerging market for environmental products and technologies. Long Range Planning, 30(2), 277-90. https://doi.org/10.1016/S0024-6301(96)00119-7

Maurer, R., M. Pitzer \& S. Sebastian. (2004). Hedonic Prices Indices for the Paris Housing Market. Allgemeines Statistisches Archiv, 88, 303-326. https://doi.org/10.1007/s101820400173

McCarty, J. A., \& Shrum, L. J. (2001). The influence of individualism, collectivism, and locus of control on environmental beliefs and behaviour. Journal of Public Policy \& Marketing, 20(1), 93-104. https://doi.org/10.1509/jppm.20.1.93.17291

Miniard, P. W., \& Cohen, J. B. (1983). Modelling personal and normative influences on behaviour. Journal of Consumer Research, 10(2), 169-180. https://doi.org/10.1086/208957

Mostafa, M. M. (2006). Antecedents of Egyptian consumers' green purchase intentions. Journal of International Consumer Marketing, 19(2), 97-126. https://doi.org/10.1300/J046v19n02_06

Mostafa, M. M. (2007). Gender differences in Egyptian consumers' green purchase behaviour: the effects of environmental knowledge, concern, and attitude. International Journal of Consumer Studies, 31(3), 220-229. https://doi.org/10.1111/j.1470-6431.2006.00523.x

Oates, C., \& McDonald, S. (2004). Recycling and the Domestic Division of Labour: is green pink or blue? Work Employment and Society, forthcoming.

Ohman, N. (2011). Buying or lying-the role of social pressure and temporal disjunction of intention assess mental and behavior on the predictive ability of good intentions. Journal of Retailing and Consumer Service, 18, 194-199. 
https://doi.org/10.1016/j.jretconser.2010.09.008

Ölander, F., \& Thøgersen, J. (1995). Understanding Consumer Behaviour as Prerequisite for Environmental Protection. Journal of Consumer Policy, 18, 345-385. https://doi.org/10.1007/BF01024160

Oliver, J. D., \& Lee, S. H. (2010). Hybrid car purchase intentions: a cross-cultural analysis. Journal of Consumer Marketing, 27(2), 96-103. https://doi.org/10.1108/07363761011027204

Olshavsky, R. W., \& W. Wymer. (1995). The Desire for New Information from External Sources. In Proceedings of the Society for Consumer Psychology. Bollmington: Printmaster.

Olson, E. L. (2013). It's not easy being green: the effects of attribute tradeoffs on green product preference and choice. Journal of the Academy of Marketing Science, 41(2), 171-184. https://doi.org/10.1007/s11747-012-0305-6

Osterhus, T. L. (1997). Pro-social consumer influence strategies: when and how do they work. Journal of Marketing, 61(4), 16-29. https://doi.org/10.1177/002224299706100402

Ozaki, R., \& Sevastyanova, K. (2010). Going Hybrid: An Analysis of consumer Purchase Motivations. Energy Policy, 39, 2217-2227. https://doi.org/10.1016/j.enpol.2010.04.024

Padel, S., \& Foster, C. (2005). Exploring the gap between attitudes and behavior: Understanding why consumers buy or do not buy organic food. British food Journal, 107(8), 606-625. https://doi.org/10.1108/00070700510611002

Paulus, C. W. M. (2002). Modelling Consumer Preferences and Technological Change: Survey of Attitudes to Hybrid Vehicles. Bachelor of Science Dissertation, Simon Fraser University.

Perrin, D., \& Barton, J. (2001). Issues associated with transforming household attitudes and opinions into materials recovery: a review of two kerbside recycling schemes. Resources, Conservation and Recycling, 33, 61-74. https://doi.org/10.1016/S0921-3449(01)00075-1

Petty, R. E., \& Caccioppo, J. T. (1986). The elaboration likelihood model of persuasion in Advances in Experimental Social Psychology. Academic Press, New York, NY, pp. 123-205. https://doi.org/10.1016/S0065-2601(08)60214-2

Pierobon, J. (2012). Can any green social networks have staying power? Social Media Today. Retrieved April 24, 2016, from http://socialmediatoday.com/node/689081.

Pieters, R. (1989). Attitudes and Behaviour in a source-separations program: a garbology approach. Delft, Eburon.

Polonsky, M. J. (1994). An Introduction To Green Marketing. Electronic Green Journal, 1(2), 1-10. https://doi.org/10.1002/9781118785317.weom090120

Prado, S. M. (2009).The European Used-Car Market at a Glance: Hedonic Resale Price 
Valuation in Automotive Leasing Industry. Economics Bulletin, 29(3), 2086-2099.

Ralf, D., Justus, H., Ricardo, L., \& Peter. R. (2007). Hedonic Prices in the German Market for Mobile Phones. Telecommunications Policy, 31, 4-13. https://doi.org/10.1016/j.telpol.2006.11.002

Rao, T., Yang, L., \& Lv, T. (2010). A theoretical model of the mechanism of low carbon consumption behavior. Jiangsu Commercial Forum, 27(11), 5-7.

Rashotte, L. (2007). The Blackwell encyclopaedia of sociology. Hoboken: Blackwell, pp. 4426-4429.

Rex, E., \& Baumann, H. (2007). Beyond ecolabels: What green marketing can learn from conventional marketing. Journal of Cleaner Production, 15(6), 567-576. https://doi.org/10.1016/j.jclepro.2006.05.013

Roberts, J. (1996). Green consumers in the 1990s: Profile and implications for advertising. Journal of Business Research, 36(2), 217-231. https://doi.org/10.1016/0148-2963(95)00150-6

Rogers, E. M. (1995). Diffusion of Innovations (4th ed.). The Free Press: New York.

Salloum, C., Azoury, N., \& Azzi, T. (2011). Board of directors' effects on financial distress: evidence of family owned businesses in Lebanon. International Entrepreneurship and Management Journal, 9(1), 1-17. https://doi.org/10.1007/s11365-011-0209-9

Samarasinghe, D. R. (2012). A green segmentation: identifying the green consumer demographic profiles in Sri Lanka. International Journal of Marketing and Technology, 2(4), 318-331. https://doi.org/10.4038/sljpsyc.v4i2.6307

Samuelson, W., \& Zeckhauser, R. (1988). Status quo bias in decision making. Journal of Risk and Uncertainty, 1(1), 7-59. https://doi.org/10.1007/BF00055564

Schiffman, L. G., \& Kanuk, L. L. (1997). Consumer behaviour. NJ: Prentice Hall.

Schlegelmilch, B. B., Bohlen, G. M., \& Diamantopoulus, A. (1996). The link between green purchasing decisions and measures of environmental consciousness. European Journal of Marketing, 30(5), 35-55. https://doi.org/10.1108/03090569610118740

Schwartz, S. H., \& Clausen, G. T. (1970). Responsibility, norms, and helping in an emergency. Journal of Personality and Social Psychology, 16, 299-310. https://doi.org/10.1037/h0029842

Schwartz, S. H. (1975). The justice of need and the activation of humanitarian norms. $\begin{array}{lllll}\text { Journal of } & \text { Social } & \text { Issues, } & 31, & 136 .\end{array}$ https://doi.org/10.1111/j.1540-4560.1975.tb00999.x

Schwartz, S. H., \& Ben David, A. (1976). Responsibility and helping in an emergency: Effects of blame, ability and denial of responsibility. Stoichiometry, 39, 406-415. https://doi.org/10.2307/3033505 
Schwartz, S. H. (1977). Normative influences on altruism. Advances in experimental social psychology, 10, 221-279. https://doi.org/10.1016/S0065-2601(08)60358-5

Schwartz, S. H., \& Howard, J. A. (1981). A normative decision-making model of altruism: Altruism and helping behaviour: Social, personality, and developmental perspectives. Hillsdale, NJ: Lawrence Erlbaum, pp.189-211.

Schwartz, S. H., \& Howard, J. A. (1984). Internalised values as moderators of altruism: Development and Maintenance of Pro social Behaviour. New York: Plenum Press, 229-255. https://doi.org/10.1007/978-1-4613-2645-8_14

Schwartz, S. H. (1992). Universals in the content and structure of values: Theoretical advances and empirical tests in 20 countries. Advances in experimental social psychology, 25(1), 1-65. https://doi.org/10.1016/S0065-2601(08)60281-6

Scott, D., \& Willits, F.K. (1994). Environmental attitudes and behaviour: a Pennsylvania survey. Environment and Behavior, 26(2), 239-60. https://doi.org/10.1177/001391659402600206

Shaw, D., \& Shiu, E. (2003). Ethics in consumer choice: a multivariate modelling approach. European Journal of Marketing, 37(10), 1485-1498. https://doi.org/10.1108/03090560310487202

Shepherd, R., Magnusson, M., \& Sjo“de'n, P. O. (2005). Determinants of consumer behavior related to organic foods. Ambio, 34(4/5), 352-9. https://doi.org/10.1579/0044-7447-34.4.352

Sigurdardottir, S. B., Kaplan, S., Moller, M., \& Teasdale, T. W. (2013). Understanding adolescents' intentions to commute by car or bicycle as adults. Transp. Res., Part D 24, 1-9. https://doi.org/10.1016/j.trd.2013.04.008

Sima, V. (2014). Green Behaviour of the Romanian Consumer. Economic Insights- Trends and Challenges, 3, 77-89.

Sinnappan, P., \& Rahman, A. A. (2011). Antecedents of green purchasing behaviour among Malaysian consumers. International Business Management, 5(3), 129-139. https://doi.org/10.3923/ibm.2011.129.139

Solomon, M. (1996). Consumer behaviour (7th ed.). Upper Saddle River, NJ: Prentice Hall.

Soon, W. L., Seng, W. T., Luen, W. K., \& Siang, J. M. L. D. ( 2013). Hybrid Vehicle Adoption - A Conceptual Study. Journal of Educational and Vocational research, 4, 165-168.

Steel, B. S. (1996). Thinking globally and acting locally? Environmental attitudes, behaviour and activism. Journal of Environmental Management, 47(1), 27-36. https://doi.org/10.1006/jema.1996.0033

Steg, L., Vlek, C., \& Slotegraaf, G. (2001). Instrumental-reasoned and symbolic-affective motives for using a motor car. Groningen: Centre for Environmental and Traffic Psychology. https://doi.org/10.1016/S1369-8478(01)00020-1 
Stern, P. C., Dietz, T., \& Black, J. S. (1986). Support for environmental protection: The role of personal norms. Population and Environment, 8, 204-222. https://doi.org/10.1007/BF01263074

Stern, P. C., Dietz, T., Abel, T., Guagnano, G. A., \& Kalof, L. (1999). A value-belief-norm theory of support for social movements: The case of environmental concern. Human Ecology Review, 6, 81-97.

Stern, P. C. (2000). Toward a Coherent Theory of Environmentally Significant Behaviour. Journal of Social Issues, 56(3), 407-424. https://doi.org/10.1111/0022-4537.00175

Stern, P. C. (2000). Psychology and the science of human- environment interactions. American Psychology, 55(5), 523-30. https://doi.org/10.1037/0003-066X.55.5.523

Stern, P. C., Kalof, L., Dietz, T., \& Guagnano, G. A. (1995). Values, beliefs, and pro environmental action: attitude formation toward emergent attitude objects. Journal of $\begin{array}{llll}\text { Applied Social } & \text { Psychology, 25(18), }\end{array}$ https://doi.org/10.1111/j.1559-1816.1995.tb02636.x

Steel, B. S. (1996). Thinking globally and acting locally? Environmental attitudes, behaviour and activism. Journal of Environmental Management, 47(1), 27-36. https://doi.org/10.1006/jema.1996.0033

Steg, L., Vlek, C., \& Slotegraaf, G. (2001). Instrumental-reasoned and symbolic-affective motives for using a motor car. Groningen: Centre for Environmental and Traffic Psychology. https://doi.org/10.1016/S1369-8478(01)00020-1

Sun, Y. (2010). A new exploration of low carbon consumption in a low carbon economy era. Journal of Shanxi Finance and Economics University, 32(S2), 63-70.

Tanner, C., \& Kast, S. W. (2003). Promoting sustainable consumption: determinants of green purchases by Swiss consumers. Psychology \& Marketing, 20(10), 883-902. https://doi.org/10.1002/mar.10101

Tan, B. (2011). The Roles of Knowledge, Threat \& PCE on Green Purchase Behaviour. International Journal of Business and Management, 6, 14-27. https://doi.org/10.5539/ijbm.v6n12p14

Thøgersen, J. (1990). A behavioural science framework for source-separation systems for household waste. Aarhus: Aarhus Business School, Department of Marketing, Working Paper.

Thøgersen, J., \& Ölander, F. (1995). Spillover of environment-friendly consumer behaviour. Journal of Environmental Psychology, 23(3), 225-236.

Thøgersen, J. (1996). Recycling and morality: A critical review of the literature. Environment and Behavior, 28, 536-558. https://doi.org/10.1016/S0272-4944(03)00018-5

Torlak, O., Ozkara, B. Y., Tiltay, M. A., Cengiz, H., \& Dulger, M. F. (2014). The effect of electronic word of mouth on brand image and purchase intention: An application 
concerning cell phone brands for youth consumers in Turkey. Journal of Marketing Development and Competitiveness, 8(2), 61-68.

Wang, Y. C., Huang, Y. C., \& Yang, M. (2014). Effects of green brand on green purchase intention. Marketing Intelligence \& Planning, 32(3), 250-268. https://doi.org/10.1108/MIP-10-2012-0105

Wang, S., Fan, J., Zhao, D., Yang, S., \& Fu, Y. (2016). Predicting Consumer's' Intention to Adopt Hybrid Electrical Vehicles: Using an Extended version of the Theory of Planned Behaviour. Transportation, 43, 123-143. https://doi.org/10.1007/s11116-014-9567-9

Webster, F. E. (1975). Determining the characteristics of the socially conscious consumer. Journal of Consumer Research, 2(3), 188-196. https://doi.org/10.1086/208631

Wenzel, E. (2009). The Social Media \& Web Guide to Going Green. Retrieved April 24, 2017 from http://mashable.com/2009/04/21/social-media-green-guide/

Williams, K., Brooks, K., \& Page, M. A. (2012). Biotechnology: Sustainability's silver bullet. Journal of Sustainability and Green Business, 1, 103-114.

Young, W., Hwang, K., McDonald, S., \& Oates, C. J. (2010). Sustainable consumption: green consumer behaviour when purchasing products. Sustainable Development, 18(1), 20-31. https://doi.org/10.1002/sd.394

Yoo, B., \& Donthu, N. (2001). Developing and validating a multidimensional consumer-based brand equity scale. Journal of Business Research, 52, 1-14. https://doi.org/10.1016/S0148-2963(99)00098-3

Tarkiainen, A., \& Sundqvist, S. (2005). Subjective norms, attitudes and intentions of Finnish consumers in buying organic food. British Food Journal, 107(11), 808-822. https://doi.org/10.1108/00070700510629760

Triandis, H. C. (1989). The self and social behavior in differing cultural contexts. Psychological review, 96(3), 506-520. https://doi.org/10.1037/0033-295X.96.3.506

van Doorn, J., \& Verhoef, P. C. (2011). Willingness to pay for organic products: differences between virtue and vice foods. International Journal of Research in Marketing, 28(3), 167-180. https://doi.org/10.1016/j.ijresmar.2011.02.005

Vermeir, I., \& Verbeke, W. (2008). Sustainable food consumption among young adults in Belgium: Theory of planned behavior and the role of confidence and values. Ecological Economics, 64(3), 542-553. https://doi.org/10.1016/j.ecolecon.2007.03.007

Vlosky, R., Ozanne, L., \& Fontenot, R. (1999). A conceptual model of us consumer willingness to pay for environmental certified wood products. Journal of Consumer Marketing, 16(2), 122-140. https://doi.org/10.1108/07363769910260498

Wahid, N. A., Rahbar, E., \& Shyan, T. S. (2011). Factors influencing the green purchase behavior of Penang environmental volunteers. International Business Management, 5(1), 38-49. https://doi.org/10.3923/ibm.2011.38.49 


\section{Macrothink}

Wang, Y. C., Huang, Y. C., \& Yang, M. (2014). Effects of green brand on green purchase intention. Marketing Intelligence \& Planning, 32(3), 250-268. https://doi.org/10.1108/MIP-10-2012-0105

Wright, R. (1994). The Moral Animal - why we are the way we are: the new science of evolutionary psychology. Abacus, London.

Young, W., Hwang, K., McDonald, S., \& Oates, C. J. (2010). Sustainable consumption: green consumer behaviour when purchasing products. Sustainable Development, 18(1), 20-31. https://doi.org/10.1002/sd.394

$\mathrm{Yu}, \mathrm{X}$. (2010). Analysis of the ways to realize low carbon consumption. Consumer Economics, 26(4), 80-82.

Zeng, Y. C., Xia, W., \& Huang, B. (2007). The consumer consciousness and corresponding influencing factors for green purchasing - based on the analysis of consumer survey in Beijing. Consumer Economics, 23(1), 38-42.

Zhang, X., \& Prybutok, V. (2005). A consumer perspective of e-service quality. IEEE Transactions, 52(1), 461-477. https://doi.org/10.1109/TEM.2005.856568

\section{Copyright Disclaimer}

Copyright for this article is retained by the author(s), with first publication rights granted to the journal.

This is an open-access article distributed under the terms and conditions of the Creative Commons Attribution license (http://creativecommons.org/licenses/by/3.0/). 